\title{
Budget Institutions and Fiscal Performance in Low-Income Countries
}

\author{
Era Dabla-Norris, Richard Allen, \\ Luis-Felipe Zanna, Tej Prakash, \\ Eteri Kvintradze, Victor Lledo, \\ Irene Yackovlev, and Sophia Gollwitzer
}




\title{
IMF Working Paper
}

Strategy, Policy, and Review, and Fiscal Affairs Departments

Budget Institutions and Fiscal Performance in Low-Income Countries ${ }^{1}$
Prepared by Era Dabla-Norris, Richard Allen, Luis-Felipe Zanna, Tej Prakash, Eteri Kvintradze, Victor Lledo, Irene Yackovlev, and Sophia Gollwitzer

Authorized for distribution by Catherine Pattillo, Michel Lazare, and Marco Cangiano

March 2010

\begin{abstract}
This Working Paper should not be reported as representing the views of the IMF. The views expressed in this Working Paper are those of the author(s) and do not necessarily represent those of the IMF or IMF policy. Working Papers describe research in progress by the author(s) and are published to elicit comments and to further debate.

This paper presents, for the first time, multi-dimensional indices of the quality of budget institutions in low-income countries. The indices allow for benchmarking against the performance of middle-income countries, across regions, and according to different institutional arrangements that deliver good fiscal performance. Using the constructed indices, the paper provides preliminary empirical support for the hypotheses that strong budget institutions help improve fiscal balances and public external debt outcomes; and countries with stronger fiscal institutions have better scope to conduct countercyclical policies.
\end{abstract}

JEL Classification Numbers:H61, H62, H63, E60, E62

Keywords: Budget Institutions, Budget Systems, Low-Income Countries, Government Debt, Government Deficits, Fiscal Policy

Author's E-Mail Addresses: edablanorris@imf.org,rallen@worldbank.org; fzanna@imf.org; tprakash@imf.org; vlledo@imf.org; and iyackovlev@imf.org

\footnotetext{
${ }^{1}$ We would like to thank Carlo Cottarelli, Hugh Bredenkamp, Andy Berg, Ian Lienert, Justin Tyson, Antonio Spillimbergo, Stefania Fabrizio, African Department's fiscal network, and participants at the Strategy, Policy, and Review Department's seminar series for comments and suggestions. Dimitar Vlahov and Sibabrata Das provided excellent research assistance.
} 


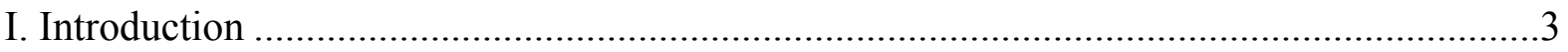

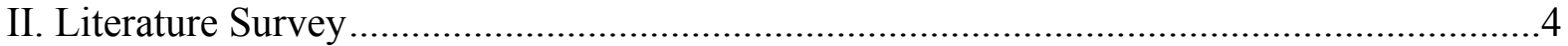

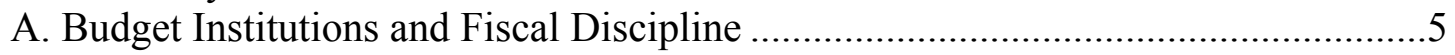

B. Budget Institutions and Procyclicality ......................................................

III. Budget Institutions in Low-Income Countries.........................................................

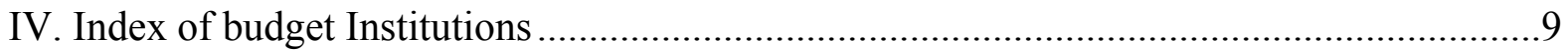

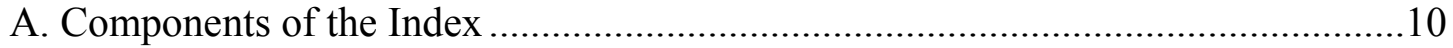

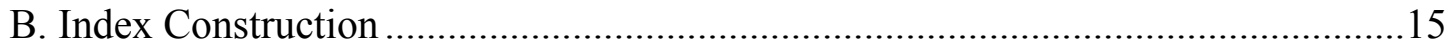

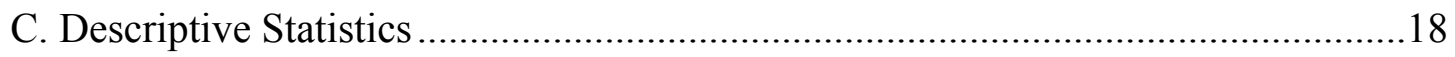

V. Budget Institutions and Fiscal Discipline ............................................................... 19

VI. Budget Institutions and Fiscal cyclicality ..........................................................23

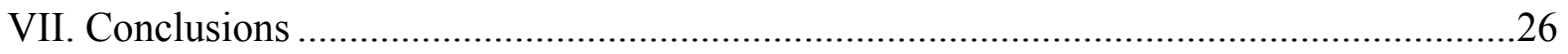

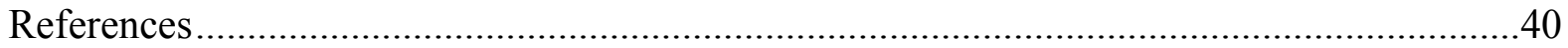

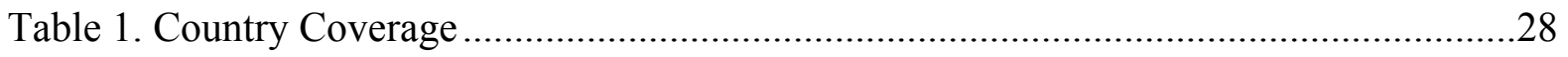

Table 2. Summary of Statistics for Budget Institutions Dimensions and Indices .................29

Table 3a. Spearman Rank Correlations among Budget Stages.........................................29

Table 3b. Spearman Rank Correlations among Categories ..............................................29

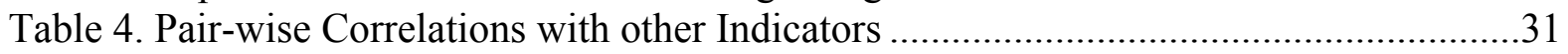

Table 5. Budget Institutions Index, by Country Groups and Stages.....................................31

Table 6. Budget Institutions Index, by Country Groups and Categories ...............................32

Table 7. Budget Institutions, Primary Balance, and External Debt ......................................33

Table 8. Disaggregated Budget Institutions and Fiscal Performance ...................................34

Table 9. Budget Institutions and Fiscal Discipline: Robustness Checks ................................35

Table 10. Robustness Checks: Role of Economy-wide Institutions .....................................36

Table 11. Budget Institutions, Fiscal Accommodation, and the Global Crisis, 2008-09........37

Table 12. Budget Institutions, Impact on Procyclicality ....................................................38

Table 13. Budget Institutions, Income and Debt, Combined Impact on Procyclicality ..........39

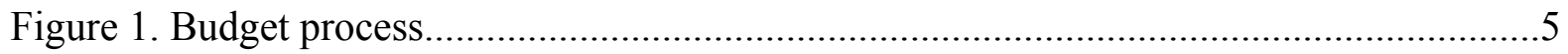

Figure 2. Budget Institutions, Country Characteristics, and Debt Vulnerabilities in LICs and

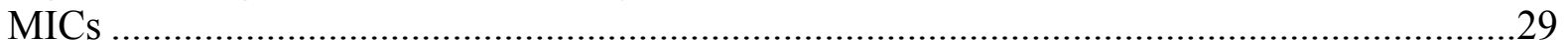

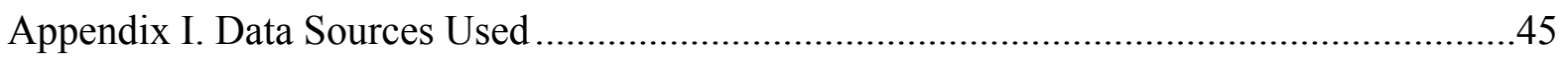

Appendix II. Dimensions, Scoring Methodology, and Sources of Data...............................46

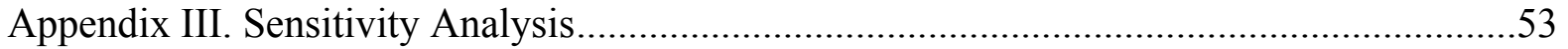

Appendix IV. Definition and Sources of Variables .........................................................56

Table A1. Spearman Rank Correlations between the Overall Indices.................................55

Table A2. Spearman Rank Correlations between the Sub-Indices ......................................55 


\section{INTRODUCTION}

Sound budget institutions are vital for a country's ability to design and implement effective fiscal policies. ${ }^{2}$ Such institutions help ensure government accountability and prevent the leakage of public funds; increase efficiency of scarce public resources; and improve the prospects of maintaining fiscal stability and meeting social development needs. Stability is more fragile, resource constraints are more binding, and social needs remain more pressing in low-income countries than in developed and emerging market countries. ${ }^{3}$ As a consequence, efforts to strengthen budget institutions have featured prominently in IMF-supported programs and donor technical assistance in the past two decades.

The current global financial crisis and its impact on low-income countries have reinforced the importance of budget institutions in enhancing the effectiveness of fiscal policy as a stabilization tool. While policymakers across different regions have sought to respond to the crisis in a counter-cyclical manner, there is evidence that certain institutional arrangements enhance the scope for countercyclical policy. As countries exit from the crisis, sound budget institutions can support the consolidation process and help safeguard fiscal sustainability.

A sizeable literature has attempted to measure the quality of budget institutions by defining quantitative indices and examining their effect on fiscal performance. The present study is the first, however, to focus attention primarily on low-income countries. It develops a composite index of the quality of budget institutions for 72 low-income and middle-income countries drawing upon empirical studies, budget survey databases and assessment reports, supplemented by case studies and other reports and data from the IMF, the World Bank, and donors engaged in capacity building in low-income countries. ${ }^{4}$

The index breaks new ground by recognizing the multi-faceted nature of budget institutions and is broader in scope than other available indicators. It records the quality of budget institutions along two dimensions. The first dimension covers the various stages in the budget process (planning and negotiation, approval, and implementation). The second dimension reflects various characteristics of the budget process: the degree of centralization of budgetary decision-making; the existence and effectiveness of rules and controls; the sustainability and credibility of the budget as a key policy instrument; and its

\footnotetext{
${ }^{2}$ Budget institutions are the structures, formal and informal rules, and procedures governing budget planning, approval and implementation. The term "public financial management" (PFM) is often used synonymously with budget institutions. However, while the two terms are similar, PFM is typically used in a narrower, and more technical sense-it is associated with systems, procedures and processes related to the budget, including expenditures, revenues and government borrowing, whereas the term "institutions" incorporates wider political economy and social influences on the budget.

${ }^{3}$ In this paper, "low-income countries" refers to all countries shown on the IMF's list of countries eligible for the Poverty Reduction and Growth Trust (PRGT) at end-December 2009.
}

${ }^{4}$ These include the Public Expenditure and Financial Accountability (PEFA) assessment framework, and the OECD-World Bank budget database. 
comprehensiveness and transparency. The choice of criteria used in constructing the index reflects specific characteristics of low-income countries. The index allows for benchmarking against the performance of middle-income countries, across regions, and according to different institutional arrangements that deliver good fiscal performance. ${ }^{5}$

Using the constructed indices, the paper provides some preliminary econometric evidence of the relationship between budget institutions and fiscal performance in low-income countries. In particular, the paper addresses two main questions: are strong budget institutions associated with greater fiscal discipline (lower deficits and debt); and do countries with stronger fiscal institutions have better scope to conduct countercyclical policies? Answers to these questions can help guide a more systematic and meaningful prioritization and sequencing of the reforms of budget institutions in low-income countries.

The paper is structured as follows. Section II summarizes the literature; Section III describes the proposed index of budget institutions, how it has been constructed, its statistical properties, and a comparison with other available indicators; Section IV presents the results of the econometric analysis of the relationship between budget institutions and fiscal outcomes; Section V presents some econometric evidence on whether countries with better institutions have been able to adopt more counter-cyclical policies, including during the current crisis; finally, Section VI draws conclusions, and discusses the policy implications of the empirical work presented in the paper.

\section{LiteratURE SURVEY}

A well established body of theoretical and empirical evidence suggests that institutional arrangements that govern the budget process influence fiscal outcomes. Budget institutions shape and regulate the policy and process of generating and allocating public resources for carrying out government functions. ${ }^{6}$ They incorporate the formal and informal rules that govern the budget process, and the relative division of roles and responsibilities among the various actors at each stage of the process (Figure 1).

The following section summarizes the literature that relates the quality of budget institutions to fiscal outcomes. We then provide a selective literature review of the link between budget

\footnotetext{
${ }^{5}$ A recent study carried out by the Fiscal Affairs Department examines the extent to which fiscal institutions in G-20 countries are sufficient to support the process of fiscal consolidation required by the global financial crisis (IMF, 2010). While our paper shares a common interest in the quality of fiscal institutions, and has a related methodological approach, it differs both in terms of the countries covered and the scope and purpose of the analysis.

${ }^{6} \mathrm{~A}$ large political-economy literature examines the role of political factors in influencing fiscal outcomes (see Perrson and Tabellini, 2000 and 2005 for a discussion of the literature).The underlying premise is that electoral and party system rules determine different configurations under which policy coalitions are formed. While the design of the budget process and a country's political institutions are undoubtedly interlinked, in this paper we confine ourselves to a discussion of the elements of the budget process that are independent of the wider political landscape.
} 
institutions and fiscal cyclicality. Finally, we discuss the special characteristics of budget processes in low-income countries that have been reflected in the choice of criteria used in constructing the index.

Figure 1. The Budget Process

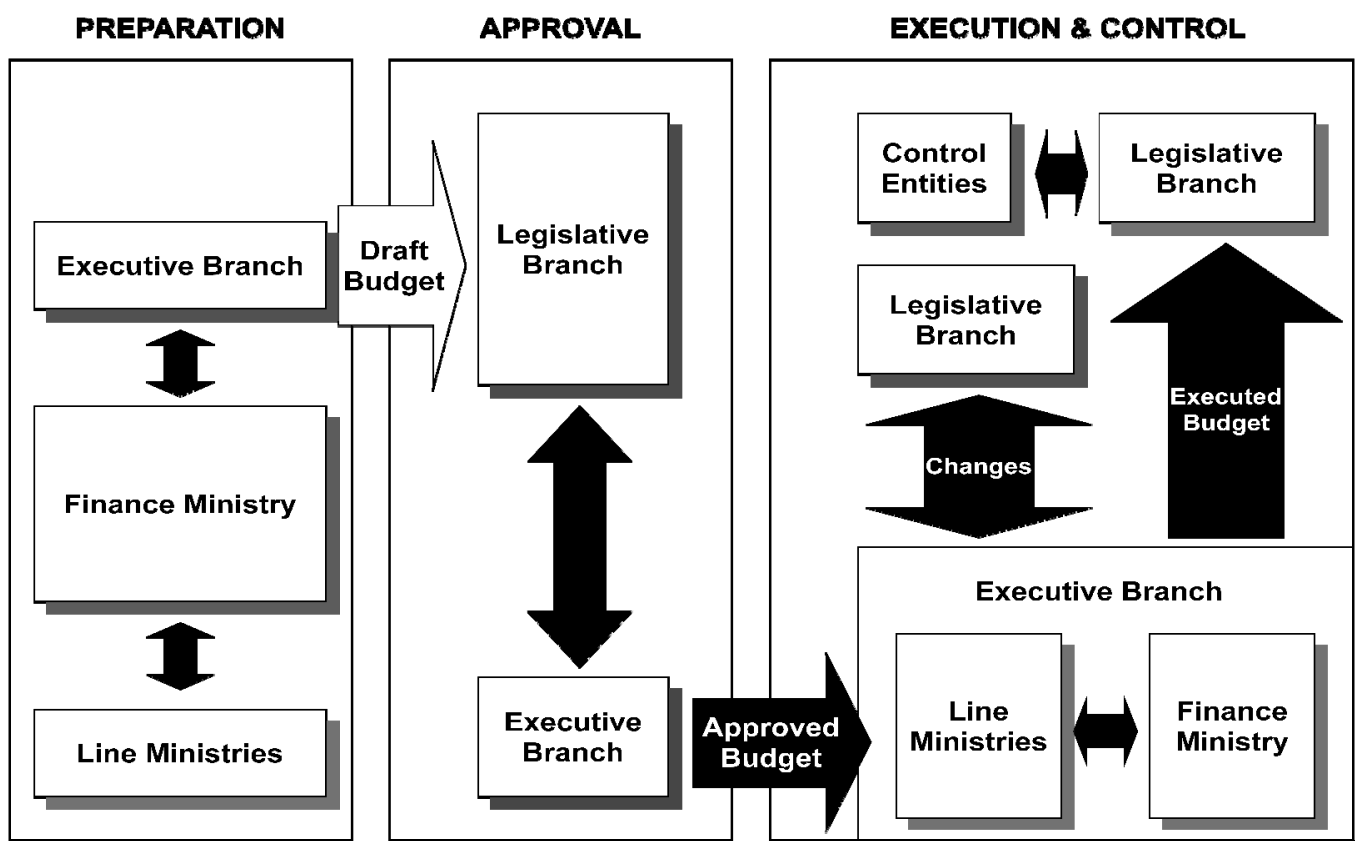

Source: Modified from Scartascini and Filc (2007).

\section{A. Budget Institutions and Fiscal Discipline}

Two distinct but interrelated theoretical phenomena have an impact on the nature of the budget process and the quality of budget outcomes. The first is the common pool phenomenon which arises when the various decision makers involved in the budgetary process (legislators, the finance minister, line ministers, etc.) compete for public resources and fail to internalize the current and future costs of their choices. ${ }^{7}$ The second pertains to information asymmetry and incentive incompatibilities- the agency phenomenon-between the government and voters and within the government hierarchy (e.g., between the ministry of finance and line ministries) which can influence the size, allocation, and use of budgeted resources. ${ }^{8}$

Unless regulated by strong institutional arrangements, the common pool phenomenon can result in a "deficit bias" in the form of excessive expenditures, deficits and debt levels (see IMF, 2010, and references therein). Strong core fiscal institutions can counteract this bias by

\footnotetext{
${ }^{7}$ See Weingast et al. (1981) and Velasco (1999).

${ }^{8}$ See Dixit (1998). For example, the agency problem arises if politicians can extract rents from being in office and appropriate public resources for themselves at the cost of voters' preferences.
} 
ensuring that the budgetary consequences of policy decisions are appropriately taken into account. The literature suggests that both a top-down approach to planning the budget and cooperative bargaining are helpful in overcoming this problem (see, among others, Hallerberg and von Hagen, 1999; Strauch and von Hagen, 2004; and Ljungman, 2009). 9 These approaches, combined with strong accountability mechanisms to minimize the agency problem, and supporting structures that comprehensively and transparently monitor and enforce budget decisions, promote fiscal discipline.

Empirical evidence on the relationship between budget institutions and fiscal outcomes, such as budget deficits and debt, has relied on the construction of numerical indices. These indices summarize key aspects of relevant institutional features with a view to gathering a wide range of information about the different phases and aspects of the budgetary process. Based on analysis of budgetary processes in EU countries, von Hagen (1992) - and subsequently von Hagen and Harden $(1994,1996)$ - find that fiscal discipline is enhanced if budgeting procedures give a strong role to the prime minister or finance minister, limit parliamentary amendments, and enforce strict execution of the budget law.

Alesina et al. (1999) was the first study to formally measure the quality of budget institutions in developing countries by creating an index comprised of 10 different components related to different stages of the budgetary process in 20 Latin American and Caribbean countries. Budget rules and regulations are divided into three types: procedural rules along a hierarchical/collegial scale, rules on transparency, and numerical targets such as balanced budget laws. The study finds that hierarchical or top-down procedures that impose a hard budget constraint and a greater level of budget transparency are conducive to greater fiscal discipline. Several recent empirical studies build on these findings to show that budgetary institutions have a significant impact on fiscal outcomes in different contexts-see, for example, Hallerberg et al. (2009) for European countries; Perotti and Kontopolous (2002) for OECD countries; Fabrizio and Mody (2006) and Mulas-Granados et al. (2009) for Central and Eastern Europe; Filc and Scartascini (2005) for Latin America, and Prakash and Cabezón (2008) for Sub-Saharan heavily indebted countries.

An important lesson to be drawn from the empirical literature is that the interaction between the rules, norms, and procedures at different stages of the budget process needs to be considered. Further, the existence of fiscal rules and medium-term planning constraints alone may be insufficient to instill fiscal discipline if a country has structural weaknesses in budgeting processes, or if institutional checks and balances are weak. In such cases, rules can be circumvented in many ways such as by creative accounting, including by generating

\footnotetext{
${ }^{9}$ The "delegation," or top-down decision making approach creates clear authority and accountability by assigning budgetary powers to a strong central player. The "contract" approach allows for a cooperative process, buttressed by transparent rules, to balance tendencies to indiscipline. In general, the choice between these two approaches is country-specific and depends on the political system. In practice, however, the two approaches are typically combined.
} 
overly optimistic forecasts of economic variables, and by strategically determining what categories of expenditure are kept off budget (Alesina and Perotti, 1999).

\section{B. Budget Institutions and Procyclicality}

The relationship between budget institutions and procyclical fiscal behavior has received growing attention in recent years. Both theoretical and empirical studies identify three broad groups of factors that explain why fiscal policy can be procyclical: (i) political and institutional factors that lead to fiscal profligacy in good times; (ii) financing constraints and limited access to international capital markets in bad times; and (iii) implementation constraints that delay and compromise the quality of policy decisions both in good and bad times. $^{10}$

Based on the common pool phenomenon described above, Tornell and Lane (1999) argue that in the absence of institutional controls to limit policy discretion, the competition for public resources in good times eventually leads governments to overspend. Such patterns, and the resulting fiscal procyclicality, have tended to be more pervasive in countries with more volatile tax bases (Talvi and Vegh, 2005), weaker budget institutions which create opportunities for rent-seeking and corruption (Alesina et al., 2008), and fewer checks on the executive (Akitoby et al., 2006). ${ }^{11}$

Financing constraints also induce procyclical fiscal behavior and may be affected by the quality of budget institutions. Weak budget institutions heighten concerns about government creditworthiness and fiscal sustainability, which may serve to exacerbate financing constraints. Financing constraints become more binding the more procyclical the source of financing (Kaminsky et al., 2004) and the more debt sustainability perceptions worsen (Alberola and Montero, 2006).

Implementation constraints have also been commonly invoked in the literature to explain procyclical fiscal responses (Balassone and Kumar, 2007). Implementation constraints are ultimately reflected in deviations between planned and executed budgets (implementation errors). A nascent literature examines the contribution of budget institutions to reducing implementation errors. In the context of the European Union, Beetsma et al. (2009) show that strong medium-term budgetary frameworks and well-enforced numerical fiscal rules help promote fiscal discipline and countercyclical policies by reducing implementation errors.

\footnotetext{
${ }^{10}$ These factors can reinforce each other. For instance, lack of political and institutional controls in bad times prevents fiscal prudence in good times. This, in turn, jeopardizes fiscal sustainability and creditworthiness, making financing constraints more binding.

${ }^{11}$ Using samples of SSA countries, Thornton (2008) finds a similar impact for corruption and Diallo (2009) corroborates the results related to institutional restraints on the executive. See also Manasse (2006).
} 


\section{BUDGET INSTITUTIONS IN LOW-INCOME COUNTRIES}

The academic literature on budget institutions in low-income countries is nascent, and originates to a large extent from the field work of donors and development agencies. In general, budget institutions in low-income countries are much less developed than in developed and emerging market countries, and display widely different characteristics that reflect country-specific factors, such as colonial heritage, and a variety of cultural and administrative traditions and practices. Evidence suggests that weak capacity, ineffectiveinstitutions of civil society, and political economy factors act as a severe constraint on the progress of modernizing budget institutions (Allen, 2009).

In low-income countries, numerical targets and formal constraints on spending and fiscal deficit that exist on paper, may not be binding in practice. This is because mechanisms that make adherence to budget rules and procedures transparent, and hold government ministers and officials accountable for their decisions, are usually not well established. In this context, enhancing the transparency and comprehensiveness of the budget process, and public dissemination of budget documents, even in the absence of formal rules, may be particularly important (Campos and Pradhan, 1996). ${ }^{12}$ This can be combined with a top-down approach to budgeting in which the finance ministry, supported by the cabinet, plays a prominent role in decision-making (Ljungman, 2009). ${ }^{13}$

Other features of budget institutions in low-income countries distinguish them from more developed and emerging market countries. For example, in many such countries, the central budget authority - usually the ministry of finance - is relatively weak in the ministerial hierarchy, and the budget is subordinate to the national plan as a policy-making instrument. Moreover, the existence of a powerful planning ministry that is responsible for preparing and executing the budget for capital expenditures fragments the budget process ("dual budgeting"). While extrabudgetary funds and accounts appear to be no more prevalent (as a percentage of government expenditure) than in developed countries, their integration with the budget process is often weaker (Allen and Radev, 2006). Moreover, many low-income countries are heavily dependent on flows of donor aid that are often not fully integrated with the budget (Gupta et al., 2008). These factors reduce transparency and accountability, render the allocation of resources according to priorities more difficult, and create parallel bargaining arenas separate from the budget process itself.

\footnotetext{
${ }^{12}$ Campos and Pradhan (1996) examine how institutional arrangements in different countries affect incentives that govern the size, allocation and use of budgetary resources, with the aim of assessing the strengths and weaknesses of different systems. For the low-income African countries analyzed, they find that the lack of adequate systems for transparency and accountability undermined the credibility of budget outcomes.

13 "Top-down" budgeting as a collective approach should be contrasted with "centralized" budgeting, in which decision-making authority is concentrated exclusively in the finance ministry, or central budget authority, and in general is not recommended for low-income countries.
} 
Weaknesses in financial reporting and audit systems in many low-income countries frequently imply that mechanisms to track whether actual expenditures are within aggregate limits are inefficient (Prakash and Cabezon, 2008; Gupta et al., 2008). Controls of spending and commitments are also characteristically weak, and arrears of spending and revenues are a familiar problem. Moreover, the absence of a sound accounting framework increases the scope for creative accounting to avoid or manipulate the government's financial regulations and other controls.

\section{INDEX OF BUDGET INSTITUTIONS}

Most quantitative indices systemize available information regarding the characteristics and functioning of the budget process, practices, and rules. Expanding on this line of research, we construct indices that are relevant to analyzing the overall quality of budget institutions in low-income countries. Our indices, however, do not attempt to provide an exhaustive catalogue of all aspects of budget institutions. The data sources that have been used-which constitute the bulk of publicly available information-focus primarily on the expenditure side of the budget, and fall short of the "ideal" index that could have been constructed if existing data sources were no impediment. For example, there are as yet few reliable indicators that measure institutional capacity in areas such as the delivery of core public services, the tracking of poverty-related spending, or revenue administration.

In constructing the index, we use several sources of data (see Appendix 1 for details). The assessments largely cover the 2006-2008 periods, and include 72 countries across different regions (Table 1). Both published and unpublished PEFA reports are the primary source of data for criteria related to budgetary practices and performance. ${ }^{14}$ However, the PEFA framework is not comprehensive: it focuses on the operational performance of the key elements of the PFM systems, rather than the legal framework and the strategic interactions between the various actors at different stages of the budget process. Moreover, it takes no account of the influence of political economy factors on the budget. Other published indicators are also selective in their focus. Information on legal regulations and numerical and procedural rules at various stages of the budget process is mostly obtained from the OECD database. Questions on the transparency and comprehensiveness of fiscal information are based on the IBP Open Budget Index, and IMF Reports on the Observance of Standards and Codes, fiscal transparency module ("fiscal ROSC"). These data sources were complemented by a survey of IMF country teams and fiscal economists. By combining these elements, our index provides a more complete picture of the budget process, and a strengthened framework for analyzing the various components.

\footnotetext{
${ }^{14}$ Developed countries were excluded from the sample because (i) such countries frequently use techniques of budgeting that are very different from those employed in low-income countries - examples include the use of accrual accounting and accrual budgeting, advanced systems of program and performance budgeting, decentralized treasury systems, and sophisticated debt management models; there is thus a discontinuity in the scope and nature of budget institutions that would be difficult to capture in a statistical and econometric analysis; and (ii) one of the main surveys we used in developing our index - PEFA assessments - includes results for only one developed country (Norway).
} 


\section{A. Components of the Index}

Following the literature, we identify three consecutive phases in the budget process: planning and negotiation; approval; and implementation. The planning and negotiation phase comprises the establishment of the overall budget, and the allocation of funds between the different line ministries and programs, using multi-annual macroeconomic and budgetary frameworks where appropriate. The approval phase comprises the legislature's hearing of, and legal adoption of the annual budget. The implementation phase includes the execution, monitoring, control, reporting, and external oversight of budgetary allocations.

At each of the budgetary stages, we identify five cross-cutting categories: (i) top-down procedures; (ii) rules and controls; (iii) sustainability and credibility; (iv) comprehensiveness; and (v) transparency. This framework allows for a two-dimensional analysis across budgetary stages and across different categories that evaluate different aspects of the quality of budget institutions. Each of these dimensions is made up of several individual criteria (33 in total). ${ }^{15}$ However, these criteria affect and are affected by each other both directly and through other channels; these also affect many other variables that are not included due to data limitations. Box 1 provides a summary of the main dimensions and components, while Appendix 2 provides a detailed description of the scoring methodology and data sources used.

\section{Top-down procedures}

As discussed in Section II, empirical evidence suggests that top-down procedural arrangements for negotiating, approving, and executing the annual budget serve to guard against the deficit bias in decision making. We define top-down budgeting as the extent to which the central budget authority (CBA), under the supervision of the cabinet or council of ministers, is given the agenda-setting role in relation to the main budgetary aggregates, ensuring compliance with the budget laws, and enforcing control of budgetary expenditures.

- At the planning stage of the budget process, the index assesses whether institutional arrangements attribute strategic powers to a CBA and the existence of a top-down structure of setting budget priorities. Line ministries and other claimants have relatively parochial views on the budget, and may create a common pool phenomenon described above. A binding top-down decision on the aggregate spending level and the sectoral or ministerial allocations at the onset of the budget process promotes fiscal discipline during budget preparation. This reduces the room for special interest pressures to enlarge the budget envelope.

\footnotetext{
${ }^{15}$ It should be noted that these components are not mutually exclusive but reinforce and inform each other. For instance, lack of comprehensiveness in the budget process, in the form of a failure to consolidate all fiscal activities into a "bottom-line" measure, reduces transparency (Poterba and von Hagen, 1999).
} 


\section{Box 1. Components of the Budget Institutions Index}

\section{Budget Planning and Negotiation}

1 Top-down Procedures

a. Is there a single central agency with responsibility for preparing the budget?

b. Is there a top-down budget formulation process?

\section{Rules and Controls}

a. Are there any numerical fiscal rules or targets?

b. Are line ministries subject to spending ceilings?

\section{Sustainability and credibility}

a. Is there a medium-term planning/budgeting framework?

b. Are sector strategies prepared, including estimates of their cost?

c. Macroeconomic and fiscal forecasting

- Are macroeconomic and fiscal forecasts prepared and presented in budget documents?

- Are alternative medium-term scenarios prepared to guide budget preparation?

- Do fiscal projections separately identify the cost implications of current and new policy measures?

\section{Comprehensiveness}

a. Are there dual budgets for recurrent and capital expenditures?

b. What is the scale of extrabudgetary expenditures?

c. Is information on domestic and external debt included in the budget?

d. Is information on donor-financed aid projects included in the budget?

e. Is information on fiscal risks included in the budget?

\section{Transparency}

a. Is there an administrative, economic and functional classification of the budget?

b. Is the government's draft budget released to the public?

\section{Budget Approval}

\section{Top-down Procedures}

a. What limits are there on the legislature's power to amend the draft budget?

b. Is there a top-down procedure for approval of the budget by the legislature?

\section{Rules and Controls}

a. Are there clear time limits on the approval of the budget by the legislature?

\section{Sustainability and Credibility}

a. What is the extent of the legislature's scrutiny of fiscal policy and the budget?

\section{Comprehensiveness}

a. What is the scope of budget documentation presented to the legislature?

\section{Transparency}

a. Does the legislature hold public hearings on the budget?

\section{Budget Implementation}

\section{Top-down Procedures}

a. How detailed are the expenditure appropriations received by spending ministries?

\section{Rules and controls}

a. Are there effective internal controls, including controls on spending commitments?

b. What are the rules and procedures for in-year amendments to the budget?

c. Is there an effective system of internal audit?

d. Is there an effective system of external audit?

\section{Sustainability and credibility}

a. Are the fiscal activities of local governments and public enterprises monitored?

b. How is domestic and external debt recorded and managed?

c. Is information available to measure the existence and scale of expenditure arrears?

\section{Transparency}

a. What accounting standards does the government use?

b. Are consolidated financial statements issued on a timely basis?

c. Are external audit reports produced on a timely basis, and scrutinized by the legislature?

$\mathrm{d}$. What is the scope and timeliness of in-year financial reports?

e. Does the government publish a reconciliation of budgeted and outturn expenditures? 
- During the budget approval stage, legislators may have an incentive to promote spending that benefits their narrow constituencies at the expense of the general public. Our index assesses the extent to which there are clear limits on the legislature's rights to amend the draft budget and the sequencing of the vote on the budget. Under a top-down procedure for voting, the legislature first votes on the main fiscal aggregates before voting the allocation of resources to different sectors, ministries or line items.

- At the budget execution stage, in order to avoid funds being misappropriated into projects that are not included in the budget, and to avoid over-spending on approved projects, line ministries or agencies should receive appropriations that specify expenditures at a sufficient level of disaggregation.

\section{Rules and Controls}

Establishing rules that put specific limits on spending and borrowing can strengthen fiscal credibility and discipline. Budgetary rules can be grouped into numerical and procedural rules and controls. ${ }^{16}$ Numerical rules are restrictions on the outturn of relevant fiscal variables which establish clear and stable objectives for fiscal policy. ${ }^{17}$ Procedural rules define the processes under which budget decisions are made and executed. They can serve to enforce fiscal rules-e.g., through inclusion of sectoral expenditure ceilings in the annual budget - and as guarantee for the compliance of actual expenditure with the budget. Ex ante internal controls, including on spending commitments, are important for reinforcing spending rules and fiscal discipline in developing countries, and particularly in low-income countries.

Our index includes the following criteria:

- At the budget planning stage, the index assesses the existence of numerical rules such as legal limits on the size of budget deficits or government borrowing as well as the use of sectoral expenditure ceilings. While they impose some measure of inflexibility, sectoral expenditure ceilings can serve as helpful guidelines for policy-makers, and can prevent overspending on showcase projects.

- At the budget approval stage, procedural rules such as time limits for the approval of the annual budget before the new fiscal year begins can potentially reduce the tendency for budget priorities to be distorted by political infighting.

\footnotetext{
${ }^{16}$ See IMF (2009a) for a discussion of the importance of numerical fiscal rules in promoting sustainable fiscal policies.

${ }^{17}$ It is widely recognized that mechanisms for accountability, monitoring, and enforcement are important elements in determining the effectiveness of fiscal rules. In low-income countries, many of these mechanisms are weak. As a result, the potential effect of numerical rules on budget outcomes may be limited. However, empirical studies suggest that national fiscal rules have been generally associated with improved fiscal performance in developing countries (Alesina et al., 1999; Filc and Scartascini, 2005).
} 
- At the budget implementation stage, the index assesses the existence of restrictions on inyear amendments to the budget. If the government can easily modify budget parameters, agreements made in the budget planning and approval stages and the credibility of the budget as a policy instrument are undermined. The index also assesses the existence and effectiveness of internal controls, and of internal and external audit.

\section{Sustainability and Credibility}

A sustainable and credible fiscal framework depends on the budget being implemented as approved, which in turn is determined by the realism of the underlying economic and fiscal projections, the extent to which the budgetary cost of policy decisions are taken into account, and the effectiveness of arrangements for overseeing and monitoring the budget process. In the absence of such conditions, the discrepancy between planned and actual spending can potentially be large, thereby undermining both fiscal discipline and the credibility of the budget as a statement of government intent.

Our index includes the following criteria:

- A medium-term framework that translates fiscal objectives or rules into a credible plan for the evolution of fiscal aggregates is important for evaluating the sustainability of policies. ${ }^{18}$ This is evaluated in two separate criteria: assessing the existence of multi-year forecasts and their linkage to annual budgetary policies; and the existence of costed sector strategies to determine whether multi-year current and new sector polices can be financed within annual aggregate fiscal targets. ${ }^{19}$

- At the budget approval stage, comprehensive and timely legislative oversight and approval is required to ensure political support for the government's fiscal policy.

- At the implementation stage, the sustainability and credibility of the budget is enhanced by efficient procedures for monitoring the fiscal position of public enterprises and local governments, which are frequent sources of government guarantees and other contingent liabilities; and for monitoring and controlling expenditure arrears and public debt. Budgetary credibility is also enhanced by public availability of timely and accurate information on budget outturns.

\footnotetext{
${ }^{18}$ Medium-term budgeting frameworks (MTBFs) can play an important role in ensuring aggregate fiscal discipline while acting as a bridge between the goals and objectives of medium-term country development strategies and the annual budget process. However, in the absence of basic budget institutions and adequate capacity they may not achieve their objectives. See, for example, Le Houerou and Taliercio (2002) and Schiavo-Campo (2009) for a discussion of the challenges that may arise in introducing such frameworks in lowincome countries.

${ }^{19}$ The latter are particularly important for improving the link between capital and recurrent budgets in lowincome countries (Gupta et al., 2008).
} 


\section{Comprehensiveness}

A comprehensive budget ensures that all elements of government revenue and expenditure are included within a consistent framework for managing public finances. It ensures greater awareness of the current state and future evolution of public finances and is an essential part of a fiscal consolidation program. It also reduces the risk of enclave budgeting, whereby certain spending programs and projects are protected by the establishment of special funds outside the purview of the annual budget (Schick, 1998). ${ }^{\mathbf{2 0}}$

Our index includes the following criteria:

- At the budget planning stage, the index measures the comprehensiveness of the coverage of the budget, captured by criteria that evaluate the existence of dual budgeting, the size of off-budgetary expenditure, the inclusion of information on donor-funded projects and public debt, and the evaluation of aggregate fiscal risks to which the government is exposed.

- At the budget approval phase, the index assesses the comprehensiveness of information contained in the budget documents presented to the legislature.

- No criteria are included at the budget implementation phase, since it is assumed that the comprehensiveness of the budget is determined during the previous two phases-the budget is executed on the basis of the appropriations approved by the legislature.

\section{Transparency}

A transparent budget process which provides the public with all relevant information in a reliable, timely, understandable, and internationally comparable manner, is key for ensuring that public officials are held accountable for managing public resources. ${ }^{21}$ Transparency throughout the entire budget process prevents hidden budgeting, another common problem in many low-income countries, where the real budget is known only to a selected few, thus facilitating the misappropriation of funds and increasing the scope for mis-governance (Schick, 1998).

\footnotetext{
${ }^{20}$ There are arguments for and against special funds. What is important is that for all operational purposes-allocation, spending and reporting - they are integrated with the budget framework (Allen and Radev, 2006).

${ }^{21}$ See Kopits and Craig (1998). The IMF's Code of Good Practices on Fiscal Transparency and the accompanying Manual of Fiscal Transparency explain the various dimensions against which transparency may be measured. Alt and Lassen (2006) develop an index measuring the transparency of budget processes in 19 OECD countries and find that greater fiscal transparency leads to lower public debt and deficits. Hameed (2005) develops an index of fiscal transparency based on IMF reports on the adherence to the Code of Good Practices on Fiscal Transparency. He shows that, for a broad range of countries, higher transparency is associated with better fiscal discipline.
} 
Our index assesses transparency at all the three stages of the budget process:

- At the budget planning stage, the index assesses the extent to which the classification of the budget is organized according to administrative categories, functions or programs, and the procedures for publication of the draft budget.

- At the budget approval stage, the index assesses the extent of public access to the legislature's hearings on the annual budget.

- At the budget implementation stage, the index assesses several criteria: (i) the scope and timeliness of in-year and annual reports; (ii) the application by the government of generally accepted accounting standards; (iii) the completeness and timeliness of the government's annual financial statements; and (iv) whether reports of the external audit agency on the financial statements are made available to the legislature and the public in a timely manner.

\section{B. Index Construction}

To capture the quality of budget institutions along each of the budget stages and across each of the categories discussed above, we developed and scored countries based on different subindices, which were combined to construct the overall index. The "stage index" is based on the aggregation of three sub-indices for each stage of the budget process (planning and negotiation, approval, and implementation). The "category index" is based on five subindices for each of the categories considered above (top-down procedures, rules and controls, sustainability and credibility, comprehensiveness, and transparency). As discussed below, the two indices are highly correlated, but their two dimensions (budget stages versus category) allow us to explore the impact and importance of their specific components on fiscal outcomes. $^{22}$

Most of the data used in the construction of the indices is qualitative in nature. For each question, a scale between 0 and 4 was used, with a higher score reflecting better performance. In answering the questions described in Box 1 and in assigning scores, it is inevitable that some degree of judgment was exercised. To minimize the degree of discretion, a set of coding rules was used, which can be found in Appendix II. The coding depended on the nature of the question. For some factual questions the coding was binary ( 0 or 4 score). Other questions allowed for a more-detailed scale for their answers, and hence greater differentiation across countries in terms of the various dimensions. ${ }^{23}$

\footnotetext{
${ }^{22}$ The complete data set including the various sub-indices will be available to researchers upon request.

${ }^{23}$ For example, answers related to the question "are there any numerical fiscal rules or targets?," under the rules and controls category of budget planning, allowed for three possible scores: 0 if there are no fiscal rules or targets, 2 if there are fiscal rules but not codified by law, and 4 if there are fiscal rules codified in the law. Answers to the question "what are the rules and procedures for in-year amendments to the budget?," allowed for four possible scores. In this case, the following four scores were assigned: $0,1.33,2.67$, and 4 .
} 
For each country, the stage index is a simple average of the sub-indices constructed for each of the stages: (i) planning and negotiation, (ii) approval, and (iii) implementation.

Each sub-index, in turn, is a simple average of the number of questions at each stage. That is, for the overall stage index we have:

$$
\text { STAGE INDEX }=\frac{1}{3} \sum_{i=1}^{3} S_{i},
$$

where the $S_{i}$ 's correspond to the value of the sub-indices of the stages

$$
\begin{gathered}
S_{1}=\text { PLANNING }=\frac{1}{14} \sum_{i=1}^{13} q_{i}, \quad S_{2}=\text { APPROVAL }=\frac{1}{6} \sum_{i=1}^{6} q_{i}, \\
S_{3}=\text { IMPLEMENTATION }=\frac{1}{13} \sum_{i=1}^{13} q_{i},
\end{gathered}
$$

and the $q_{i}$ 's are the scores for each of the questions, weighted according to the number of questions in each stage. For example, since the budget planning and negotiation stage has 14 questions, the score on each question receives a weight of $1 / 14$ (see Box 1). ${ }^{24}$

Similarly, the category index is a simple average of the sub-indices constructed for each of the categories: (i) top-down procedures, (ii) rules and control, (iii) sustainability and credibility, (iv) comprehensiveness, and (v) transparency across all stages of the budget process. That is,

$$
\text { CATEGORY INDEX }=\frac{1}{5} \sum_{i=1}^{5} C_{i},
$$

where the $C_{i}$ 's correspond to the value of the category sub-indices

$$
\begin{gathered}
C_{1}=\text { TOP }- \text { DOWN }=\frac{1}{5} \sum_{i=1}^{5} q_{i}, \quad C_{2}=\text { RULES }=\frac{1}{7} \sum_{i=1}^{7} q_{i}, \\
C_{3}=\text { SUSTAINABILITY }=\frac{1}{7} \sum_{i=1}^{7} q_{i}, \quad C_{4}=\text { COMPREHENSIVENESS }=\frac{1}{6} \sum_{i=1}^{5} q_{i},
\end{gathered}
$$

\footnotetext{
${ }^{24}$ For the construction of the planning and negotiation sub-index, the questions associated with macroeconomic and fiscal forecasting are considered as one question. Therefore, they are averaged and assigned a weight of $1 / 14$.
} 


$$
C_{5}=T R A N S P A R E N C Y=\frac{1}{8} \sum_{i=1}^{8} q_{i},
$$

and the $q_{i}$ 's are the scores for each of the questions, weighted according to the number of questions in each category.

Table 2 reports the summary statistics for the two overall indices and the sub-indices. A simple inspection reveals that the two overall indices show similar properties. The stage index is highly correlated (correlation of 0.97 ) with the category index. The sub-indices for stages and categories, however, show some variation. In particular, across budget stages and categories, budget planning and negotiation and comprehensiveness, respectively, have the highest standard deviations.

As is common practice in the literature, we start by looking at the Spearman rank-order correlations. Tables $3 \mathrm{a}$ and $3 \mathrm{~b}$ report these correlations among the three budget stages and 5 categories. The sub-indices for planning, approval, and implementation are significantly correlated with the overall stage index (Table 3a). However, there are some interesting differences across budget stages. In particular, budget planning and negotiation appears to be correlated with approval and implementation, while the budget approval stage has a very low correlation with implementation. Spearman rank correlations for the category index and its components show that the top-down procedures sub-index has the lowest correlation with the overall index, while the sustainability and credibility sub-index shows the highest correlation (Table 3b). In general, the sub-index for top-down procedures has low, albeit significant, correlations with the other dimensions of budget institutions. In contrast, the sub-indices for rules and control, sustainability and comprehensiveness, and transparency are highly correlated.

Sensitivity analysis was carried out to check the robustness of our indices to alternative aggregating and weighting procedures (Appendix III). In particular, different weights and assumptions about the degree of substitutability and complementarity of components were considered. The rank order correlations between the different approaches are high and significant, suggesting that the additive aggregation procedure described above is robust to alternative specifications.

We also compare our indices with existing indicators on the quality of budget institutions and governance and accountability. Table 4 shows pair-wise correlations of our indices with PEFA indicators, a sub-index of the World Bank's Country Policy and Institutional Assessment (CPIA), and the Kaufmann and Kraay governance indicators. ${ }^{25}$ The correlations of the aggregate indices with the sub-CPIA index and the PEFA indicators are high. The

\footnotetext{
${ }^{25}$ The sub-CPIA is constructed using two CPIA components that are policy-related (debt and fiscal) and three that rate the quality of public financial management and institutions. This was one of the indicators, the other being PEFA, used in assessing country capacity to manage public resources in the IMF's new debt limits policy (See http://www.imf.org/external/pp/longres.aspx?id=4359).
} 
aggregate indices are also positively and significantly correlated with the government effectiveness and regulatory quality components of the governance indicators. ${ }^{26}$ Overall, high correlations with other indices instill confidence that the new indices capture meaningful information.

Given the high correlation between the overall stage and the category indices, as well as the results from the previous sensitivity analysis, in what follows we focus on the overall stage index.

\section{Descriptive Statistics}

Some basic descriptive analysis of the data set we compiled is suggestive of relative strengths and weaknesses in budget institutions across different country groups. Across regions, transition economies followed by countries in Latin America and the Caribbean, have relatively more developed budget institutions (Tables 5-6). Countries in Sub-Saharan Africa (SSA) are characterized by weaknesses in all the budget stages, as well as in the sustainability and credibility of their budget institutions. The transparency of the budget process is a weak area across all regions included in the sample.

In general, low-income countries have weaker budget institutions than middle-income countries (Figure 2 and Tables 5-6). ${ }^{27}$ Across budget stages, while both groups of countries on average exhibit similar low scores for the budget approval stage, budget planning and implementation are considerably weaker in low-income countries. Across categories, both groups of countries are characterized by relatively high scores for top-down procedures. However, low-income countries are significantly weaker along all the other dimensions.

There is considerable diversity within low-income countries with respect to the quality of their budget institutions (Figure 2, Panels 2 and 3). Blend countries (under the World Bank's classification) have stronger planning and approval processes and score consistently higher than other country groups in all categories. Resource rich countries (oil exporters) have the weakest budget institutions along all dimensions. Low-income countries in SSA, on average, have weaker institutional capacity than other countries, particularly in the areas of sustainability and credibility, comprehensiveness, and transparency of the budget process.

\footnotetext{
${ }^{26}$ Pair-wise correlations for the more disaggregated categories indices with the two Kaufmann and Kraay governance indicators are also relatively high for transparency, comprehensiveness and sustainability of the budget process.

${ }^{27} \mathrm{~A}$ t-test of difference in means for the two groups of countries is statistically significant for the overall stage and category indices. The significance increases if we exclude low-income countries classified as "blend" by the World Bank's International Development Association (IDA) i.e., countries that are considered sufficiently creditworthy to borrow from the IBRD.
} 
The overall scores, however, mask important differences across countries. ${ }^{28}$ Countries with weaker budget institutions also tend to be in higher levels of debt distress (Figure 2 and Panel 3).

\section{BUdGet InSTITUTIONS AND FisCAL DisCIPLINE}

A steady improvement in fiscal performance has been a key feature of many low-income countries since the early 2000s. Better policy and economic management, coupled with a favorable external environment, especially terms of trade improvements, and official debt relief contributed to the stronger fiscal positions (IMF, 2007). While a large number of countries achieved primary fiscal surpluses, supported by debt relief, and reduced externaldebt burdens, cross-country variations in fiscal performance remain. In this section, we empirically investigate whether budget institutions play a role in explaining cross-country differences in fiscal outcomes, controlling for other factors.

We examine the relationship between budget institutions and fiscal discipline during 2003$2007 .{ }^{29}$ Consistent with the literature, we consider two measures of fiscal discipline: the average primary balance of the central government and the average public external debt owed to official creditors, both expressed as ratios to GDP. We focus on the average primary balance as a preferred measure of the government's fiscal stance because it abstracts from the effect of inflation on interest payments, and the fact that interest payments are a function of accumulated debt and not the present fiscal stance. The reason to focus on debt is that primary deficits in some countries may not be driven by a systematic bias but rather reflect temporary effects. We use official public external debt as the data on total government debt was limited for a large number of countries in the sample.

In conducting the empirical analysis, we estimated a cross-section OLS regression with the selection of control variables being dictated by the existing literature. ${ }^{30}$ The index and subindices were added to the regressions to test if budget institutions are related to the variable of interest after accounting for the selected control variables. The empirical analysis is crosssectional in nature because the budget institutions indices lack time variation. We exclude outliers and consider only those countries for which all variables are available. ${ }^{31}$

\footnotetext{
${ }^{28}$ For example, Tanzania and Uganda score relatively high in these categories relative to other SSA countries.

${ }^{29}$ Since the budget institutions indices were based on information collected in 2006-2008, considering a period further back in time may not be meaningful. We do not consider the post-2007 period as fiscal positions in many countries were affected by the food and fuel crisis, and subsequently by the global financial crisis.

${ }^{30}$ See Alesina et al. (1999); Alt and Lassen (2006); Filc and Scartascini (2005, 2007); and Fabrizio and Mody (2006) for details.

${ }^{31}$ Conventional tests indicated the presence of outliers among the country observations, particularly in the case of external debt. To reduce the impact of outliers, the analysis is limited to countries with external debt within two standard deviations of the overall mean debt levels. As a result three countries were dropped from the analysis (Congo DRC, Liberia, and Gambia).
} 
The selection of control variables relies on the earlier literature, which serves as a benchmark to compare our results. The control variables include real economic growth (Growth) to control for economic circumstances, the log of initial GDP per capita in 2002 (Initial GDP per capita) to control for differences in economic and overall institutional development, a dummy for HIPC post-completion point countries (HIPC), a dummy for oil-exporting countries (Oil), and the initial debt-to-GDP ratio (Initial_debt). Following Alesina et al. (1999), changes in the terms of trade (Trade) are scaled by the degree of openness of the economy, measured as the sum of exports and imports to GDP. Since in some countries tax revenues are heavily linked to export activities, we expect improvements in the terms of trade to be associated with lower deficits and debt levels, and these effects to be more important for economies that are more open to international trade. Initial debt, proxied by external debt in the year prior to the beginning of the sample (2002), is included to focus on the effect of budget institutions on recent fiscal policy settings. The HIPC dummy controls for lowincome countries that have benefited from official debt relief and, as a result, are expected to have stronger fiscal positions. Growth, terms of trade changes, and openness are measured as annual averages for the period 2003-2007 to control for cyclical effects. Appendix IV contains details on the variables and data sources.

Table 7 shows the relationship between budget institutions and primary balances and external debt including all control variables. The overall stage index of budget institutions is positively and significantly associated with the primary fiscal balance, suggesting that, consistent with the literature, countries with better budget institutions are likely to have higher fiscal balances (Column 2). ${ }^{32}$ Similar results are obtained when a sample excluding oil-exporting countries and a sample of non-oil exporting low-income countries is considered (Columns 3-4). ${ }^{33}$ To give a sense of the magnitude of the effect of budget institutions on primary balances, consider that the difference between the index value of the average "low quality" budget institutions country and the average "high quality" country is 0.8 in the full sample. Therefore, using the estimate from column 2 of Table 7, an average high quality budget institutions country is predicted to have a primary balance that is around 1 percentage points higher than a low quality country. ${ }^{34}$

Columns 6-8 of Table 7 show that stronger budget institutions are also associated with lower debt. The coefficient on the overall index is statistically significant and negative at the 5 percent level, suggesting that, consistent with the findings from previous studies, countries with better budget institutions tend to have lower debt. The strong association between

\footnotetext{
${ }^{32}$ These results also hold with the overall category index.

${ }^{33}$ The coefficient on the overall index is positive but insignificant when all low-income countries, including oilexporting countries, are considered (not reported here). The significance of the budgetary institutions variables, however, increases when oil-exporting countries are excluded from the sample. As discussed earlier, this reflects the fact that fiscal positions in the latter improved significantly for the period under consideration while the quality of budget institutions is the weakest among all country groups.

${ }^{34}$ High and low values are defined by the sample median.
} 
budget institutions and debt suggests that while the cross-country variation in external debt levels reflects past policies, there could be hysteresis in budget institutions since they are slow to evolve and difficult to change. Overall, our results seem to suggest a positive relationship between the strength of budget institutions in a country and their fiscal performance in the period leading up to the current crisis.

Disaggregating the overall index into different dimensions allows us to shed some light on which components of budget institutions are most relevant. Table 8 reports cross-country regressions for primary balance and public external debt in which the sub-indices for stages and categories are entered separately. Across budget stages, planning and negotiation appears to be driving the results with significant estimated coefficients. Across categories, one clear result is that more comprehensive and transparent budget processes have the most pronounced influence on both primary balances (Panel A). Moreover, both robust budget planning and implementation are also associated with lower debt (Panel B). In addition, stronger rules and controls and a more sustainable and credible budget process have a significant influence on debt levels. ${ }^{35}$ The differences in the relative importance of the various sub-indices, reflect, in part, the larger cross-country variation in external debt levels relative to primary balances in the period under consideration. Overall, our results suggest that, with the exception of top-down procedures, the various components of the budget institutions have an impact on performance.

To determine whether the results are driven by special cases, we ran a number of robustness checks, estimating our baseline regressions with additional variables and different subset of countries. To control for the possibility that lower primary deficits in low-income countries are driven by the inability to borrow domestically on account of less-developed financial institutions, we included credit extended to the private sector from banks and other financial institutions (as share of GDP) as a proxy for financial development. Table 9 (Columns 1 and 3) shows that financial development does not have an important independent effect on primary balances or debt. External factors (e.g. an IMF program) may also play a significant role in some countries. To control for the possibility of de facto fiscal controls, we use a dummy variable that takes a value of 1 if the country has an IMF program in the period under consideration. The results for budget institutions are robust to the inclusion of this variable (Columns 2 and 4). Our results also remain significant if we substitute average yearly growth in external debt as the dependent variable and if non-oil exporting countries and low-income countries are considered separately. We also considered different time periods for the analysis and a sample excluding HIPC countries, but the results remained largely unchanged. ${ }^{36}$

\footnotetext{
${ }^{35}$ Similar results are obtained if a sample of only low-income countries is considered (not reported here).

${ }^{36}$ As additional robustness checks, we included other variables in the regression such as inflation, population, demographic variables such as the percentage of young and old people relative to the working population, a dummy for armed conflict, an index of ethnic fractionalization, a dummy for legal origin, and dummies for SSA and the Latin America and the Caribbean region (not reported here for brevity, but available upon request).
} 
These results presented here should be considered as preliminary, since there are a number of econometric problems that need to be addressed. First, is the problem of endogeneity - the possibility that fiscal outcomes influence the evolution of budget institutions, rather than the other way around. In many low-income countries, enhancements to budget institutions are often part of a larger package of fiscal consolidation under IMF-supported programs. In this sense, budget institutions can be viewed, to some extent, as endogenous to current and past fiscal outcomes. This makes it difficult to claim a strong causality between budget institutions and fiscal outcomes, but correspondence between them is a significant result. ${ }^{37}$ The working assumption in earlier papers, which we maintain, is that budget institutions are relatively costly to change and are stable over at least the short to medium-term as changes in fiscal performance cannot quickly feedback into altering institutions.

A second problem is that of omitted variables, which arises if variables omitted from the regression are those really driving the relationship between budget institutions and fiscal performance. For example, it could be that countries with a strong overall institutional infrastructure exhibit greater fiscal discipline. Good economy-wide institutions are correlated with the quality of budget institutions, but it may be that it is other institutions excluded from the regression that really drive fiscal performance. Failure to control for this could overstate the effect of budget institutions on primary balances and debt. To partially tackle this problem, we included broad indicators of institutional quality such as government effectiveness and the control of corruption in the baseline regression (Table 10). ${ }^{38}$ The effects of budget institutions on fiscal discipline are very close to, although slightly smaller for primary balance as a percent of GDP than, the estimates obtained in the baseline regression. While these robustness checks provide some assurance, the lack of time dimension in our indices renders it difficult to adequately control for other unobservable factors.

Finally, a related problem is that of measurement error-given subjectivity involved in their construction, our indices may not be an accurate representation of the actual quality of budget institutions in countries. If this is the case, then using OLS as an estimation method can give biased results. To tackle this problem, we adopt an instrumental variable strategy that uses as an instrument a second index that is a non-linear transformation of the original index. ${ }^{39}$ In our analysis, a natural candidate corresponds to the index with different

Many of these variables were statistically insignificant, but our results on the link between budget institutions and fiscal discipline are largely robust to their inclusion.

${ }^{37}$ The endogeneity problem is widely recognized in the literature, but not easily resolvable as identifying the exogenous component of budget institutions (through the use of an appropriate instrument) is difficult.

${ }^{38}$ These are 2007 values for the two World Bank Governance Indicators.

39 Arcand and Dagenais (2005) suggest that a non-linear transformation of a variable based on sample moments of higher order than two can serve as an instrument for the original variable under two assumptions: (i) measurement errors of the variable which is to be instrumented are normally distributed; and (ii) errors are independent between observations and not between variables. In our case, there is no reason to assume that measurement errors should be correlated across countries, while within countries there is likely to be similar measurement error across different variables. Standard normality tests also fail to reject the null of normality. 
assumptions about the substitutability of its components ( $\alpha=2$; see Appendix III for details). The results for the IV 2SLS regressions for external debt, and the average yearly growth of external debt, which are available upon request, show that the effects of budget institutions on fiscal discipline are very close to, although slightly smaller than, the estimates obtained by OLS.

\section{BUDGET INSTITUTIONS AND FISCAL CYCLICALITY}

A large number of low-income countries have used fiscal policy to counter the impact of the global economic slowdown (IMF, 2009b). This apparent shift toward countercyclical fiscal policies in response to the crisis can be largely attributed to the steady improvement in macroeconomic performance and structural reforms over the last three decades. ${ }^{40}$ Among the minority of countries that instead tightened their fiscal policy, initial debt levels were significantly higher. In this section, we ask whether countries with stronger budget institutions have adopted less procyclical fiscal policies in response to the global crisis and also over the past decade.

Why should budget institutions play a role in shaping the fiscal response to the cycle? As discussed earlier, budgetary spending tends to expand during booms, often resulting in increased spending commitments which are difficult to rescind. Well-designed and efficiently managed budget institutions can enable policymakers to adopt a countercyclical policy stance by reducing the deficit bias noted in the literature, raising awareness about the medium term implications of policy actions, and by highlighting the need for sustainable policies.

As a first step, we examine whether the quality of budget institutions in low-income countries played a role in shaping fiscal policy responses to the recent global crisis. We consider two measures of fiscal accommodation in 2009: real growth in central government expenditures and the change in the primary fiscal balance (a negative sign implies higher fiscal accommodation). We estimate a cross-section OLS regression with a parsimonious set of variables to control for cross-country variation and differences in key indicators at the outset of the crisis. The control variables include primary balance in 2008 (Primary Balance lagged), external debt to GDP ratio in 2006 (Debt lagged), a dummy variable for oilexporting countries (Oil), real GDP growth, and the log of GDP per capita in 2006 to control for differences in economic and institutional development.

Table 11 details the results of the cross-section estimation. It shows that controlling for initial debt and primary balances, fiscal accommodation in 2009 was higher for countries with stronger budget institutions. The coefficient of the overall stages index is significant at the 510 percent level regardless of whether the change in the primary balance or real growth in

\footnotetext{
${ }^{40}$ This contrasts with some cross-country evidence that fiscal policy in developing countries has been mostly procyclical in the past (Iltezki and Vegh 2008). Some recent work for SSA countries singles out financing restrictions and improvements in fiscal discipline, as measured by reductions in public external debt, as an important factor in diminishing procyclicality in the region (Lledó et al., 2009).
} 
central government spending is considered as the relevant dependent variable. This finding provides some preliminary support for the idea that countries with stronger budget institutions were more likely to implement a countercyclical policy response during the Crisis - or at least be less procyclical. ${ }^{41}$

To examine whether developing countries with better budget institutions have adopted less procyclical policies over the past decade, we consider the following model:

$$
F_{i, t}=\alpha+\beta Y_{i, t}+\delta F_{i, t-1}+\theta Z_{i t}+\mu_{i}+\varepsilon_{i, t}
$$

where $F$ and $Y$ measure the real expenditure growth and output, respectively; $i$ denotes the country and $t$ the time period; $Z$ is a set of control variables, and $\mu_{i}$ is a country level fixed effect. The (pro)cyclicality of fiscal policy is determined by looking at the sign and size of coefficient $\beta$ : if $\beta<0$, fiscal policy is countercyclical; if $\beta=0$ it is acyclical; and if $\beta>0$ it is procyclical.

Since our budget institutions indices lack time variation, following Alt and Lassen (2006), we adopt an indirect approach to examine the link between the quality of budget institutions and the extent of fiscal procyclicality across countries. We replicate the analysis in Lledo et al. (2009), using annual data for 70 countries in the period 2000-2009 for which we have constructed indices. In particular, we estimate equation (1) separately for countries with weak and strong budget institutions using the median sample value of the overall budget institution index and each of the sub-indices as alternative thresholds. ${ }^{42}$ Differences in the magnitude and significance of the procyclicality parameters for the two groups of countries provide evidence of the relative importance of budget institutions.

In line with the recent empirical literature, we use a Difference GMM approach to address the reverse causality between output growth and fiscal policy as well as the correlation between output growth and country fixed effects. ${ }^{43}$ We use growth in real central government spending as the dependent variable, consistent with the argument developed by Kaminsky et al. (2004) that policy instrument variables under the direct control of fiscal authorities rather than outcome or target variables are a more appropriate way to measure the cyclicality of fiscal policy. ${ }^{44}$ Our choice of real GDP growth to proxy changes in the business cycle rather

\footnotetext{
${ }^{41}$ The results for budget institutions are robust to the inclusion of measures of borrowing constraints (private credit to GDP) as well as a dummy for IMF program in 2008 (not reported here, but available upon request).

${ }^{42}$ Ideally the impact of budget institutions on the fiscal cycle should be estimated by expanding (1) to include the interaction between $Y$ and the budget institution index $(B I)$ and $B I$ itself as an additional control (i.e. $\beta=$ $\left.\beta_{1}+\beta_{2} B I\right)$. However, the lack of time variation in the budget index precludes us from following this approach.

${ }^{43}$ We use only output growth lags as instruments. See Lledó et al. (2009) for a detailed discussion of methodological issues in the estimation of fiscal cycles, including the choice of instruments.

${ }^{44}$ Fiscal balance and tax revenues are less appropriate for measuring the cyclicality of fiscal policy because they reflect outcomes that are only partially determined by policymakers and are themselves likely to be affected by fluctuations in the output cycle.
} 
than output gap reflects recent critiques on the appropriateness of detrending output in developing countries (see Aguiar and Gopinath, 2007). See Appendix IV for details on variables and data sources used.

We find preliminary evidence that fiscal policies have on average been less procyclical over the last decade in countries with strong budget institutions (Table 12). The estimated fiscal procyclicality coefficient is statistically significant in countries with below median values for the composite index of budget quality. Fiscal policy is also procyclical in a statistically significant way for countries with index values above the sample median. However, the procyclicality coefficients in this group were about $2 \frac{1}{2}$ times smaller than in the group with index values below the median. ${ }^{45}$ Overall, this provides support for the hypothesis that high quality budget institutions are associated with less procyclical fiscal policies. However, these results should be treated with caution in light of the econometric problems outlined in the previous section.

We also find some evidence that fiscal procyclicality appears to be mostly driven by weaknesses in the initial stages of the budget process. Table 12 shows that fiscal procyclicality coefficients are statistically significant for countries with planning and approval sub indices below median values and more than twice the level of countries with higher quality budget institutions countries. By contrast, fiscal procyclicality in countries with higher scores on the implementation sub-index, although larger than in below-median score countries, is not significant at conventional levels. Our preliminary results also seem to suggest that a more transparent budget process plays a more important role in shaping fiscal cycles than other characteristics. Unlike other budget characteristics, fiscal procyclicality coefficients in countries with stronger budgetary transparency are nearly twice as small as those with less transparent budgets.

Since financing restrictions and improvements in fiscal discipline seem to play an important role in shaping past fiscal responses to the cycle among low-income countries, we next interact the composite indexes and their subcomponents separately with a low-income country dummy and with the level of external debt. The pattern of results remains qualitatively the same in both cases (Table 13). We find that fiscal policy is strongly procyclical in low-income countries, with elasticities of government spending to output growth above those displayed by countries in the full sample. Moreover, income levels appear to magnify the effect of budget institutions on fiscal procyclicality. Differences in fiscal procyclicality estimates between low-income countries with below and above median values for the composite index is about four fold. ${ }^{46}$ Similar results also apply to more

\footnotetext{
${ }^{45}$ The null hypothesis that the coefficients for the two groups of countries are not significantly different is comfortably rejected.

${ }^{46}$ The same applies to SSA countries (results available upon request) where the size and precision of fiscal procyclicality estimates are even larger than in the case for all low-income countries.
} 
indebted countries, where weak budget transparency once again stands out as detrimental to countercyclical fiscal policies.

\section{Conclusions}

This paper presents, for the first time, multi-dimensional indices of the quality of budget institutions in low and middle-income countries. While drawing on earlier studies, the paper goes further in developing a methodology that is more robust, comprehensive, and consistent than previous work. The quality of budget institutions is evaluated by means of indices that aggregate indicators across different stages and categories of the budget process to reflect institutional arrangements that deliver good fiscal performance. The indices presented in the paper allow for cross-country comparisons as well as nuanced policy-relevant analysis and identification of specific areas where reform efforts should be prioritized.

The constructed indices are used to empirically investigate whether strong budget institutions are associated with desirable fiscal outcomes. We provide preliminary evidence that sound budget institutions promote fiscal discipline, as measured by higher primary balances and lower debt, and are relevant for shaping less procylical responses to the fiscal cycle in lowincome countries, including during the current crisis. These results are consistent with earlier studies for developed and emerging market countries.

The analysis suggests that the most significant institutions are those related to planning and implementing the budget, and to the sustainability, comprehensiveness, and transparency of the budget process. These results, however, should be regarded with caution given the limitations of the econometric exercise. They do not suggest that factors appearing to be less statistically significant are unimportant for the future development of budget institutions, though they may have a limited impact on existing institutions. In developing countries, institutions such as the legislature and the external audit agency often struggle to establish a foothold in fiscal decision-making. Similarly, top-down budgeting, while accepted practice in many advanced countries, is difficult to set root in countries in which the role of cabinet is relatively minor and the centers of government are weak.

What preliminary conclusions can be drawn from these results which would merit further research? First, more work is needed to develop a comprehensive index of budget institutions along the lines suggested in this paper. Although the scope of our index is wider than other publicly available measures, the methodology outlined in the paper could be usefully extended to other dimensions, to broaden country coverage, and to introduce a time dimension into the analysis. The latter could provide evidence on the effects of changes in budget institutions and strengthen the econometric analysis. Moreover, the data we have used are drawn from many different sources which is not ideal in terms of their reliability and consistency. Nevertheless, the index we have constructed seems preferable to other indices (e.g., PEFA indicators) that present an incomplete picture of the complex dimensions of budget institutions. It is hoped that future revisions to the PEFA framework will take our work into account. 
Second, while budget institutions seem to matter for shaping fiscal responses to the cycle in low-income countries, they could matter more for their ability to ensure adequate financing in bad times than for containing overspending in good times. A fruitful direction for future research would be to examine the link between budget institutions and financing constraints in good and bad times.

Third, turning to the budget characteristics, the fact that a more transparent and comprehensive budget seems to matter more than rules and top-down procedures may indicate that, for low-income countries, budget procedures that facilitate external monitoring are more credible mechanisms for ensuring proper fiscal responses than procedures that facilitate government self-monitoring. This in turn may reflect the absence of adequate institutional checks and balances holding executive branches accountable for observing (and complying with) budget rules and controls. In other words, procedural checks and balances in the budget, in the absence of "deeper" checks and balances in the political system, are not effective. A further possible implication of this result is that, in low-income countries, greater centralization of the budget process in the hands of the executive, in the absence of strong transparency requirements and public oversight, may be actually counterproductive for fiscal discipline.

Finally, the indicators may be useful in guiding countries toward areas of the budget process that require technical assistance for building stronger institutions. It would also be interesting, but beyond the scope of the present paper, to study econometrically the extent to which technical assistance provided by the IMF, the World Bank, and others has actually been helpful in strengthening the institutions that have been the target of such assistance; and what lessons can be learned in directing, prioritizing, and sequencing these support activities in the future. 
Table 1. Country Coverage

Low-income Countries Low-income Countries

Middle-income Countries

\begin{tabular}{lll}
\hline Afghanistan & Nepal & Barbados \\
Albania & Niger & Botswana \\
Armenia & Pakistan & Colombia \\
Azerbaijan & Papua New Guinea & Costa Rica \\
Benin & Rwanda & Dominican Republic \\
Burkina Faso & Samoa & Ecuador \\
Burundi & São Tomé \& Príncipe & Egypt \\
Cameroon & Senegal & Fiji \\
Cape Verde & Sierra Leone & Indonesia \\
Chad & Sudan & Jordan \\
Congo, DR & Tajikistan & Kazakhstan \\
Côte d'Ivoire & Tanzania & Macedonia, FYR \\
Ethiopia & Togo & Mauritius \\
Gambia, The & Uganda & Morocco \\
Georgia & Yemen & Namibia \\
Ghana & Zambia & Paraguay \\
Guinea & & Peru \\
Honduras & & Philippines \\
Kenya & & Russia \\
Kyrgyz Republic & & Serbia \\
Liberia & & Seychelles \\
Madagascar & & South Africa \\
Malawi & & Swaziland \\
Maldives & & Thailand \\
Mali & & Trinidad \& Tobago \\
Moldova & & Turkey \\
Mongolia & & Ukraine \\
Mozambique & & West Bank \& Gaza \\
& & \\
\hline & &
\end{tabular}


Table 2. Summary of Statistics for Budget Institutions Dimensions and Indices

\begin{tabular}{lccccccc}
\hline & Mean & Std. Deviation & Min & Max & $\begin{array}{c}\text { 25th } \\
\text { Percentile }\end{array}$ & Median & $\begin{array}{c}75 \text { th } \\
\text { Percentile }\end{array}$ \\
\hline Planning $\left(\mathrm{S}_{1}\right)$ & 2.078 & 0.705 & 0.286 & 3.476 & 1.667 & 2.119 & 2.536 \\
Approval $\left(\mathrm{S}_{2}\right)$ & 1.998 & 0.663 & 0.778 & 3.333 & 1.445 & 2.112 & 2.445 \\
$\quad$ Implementation $\left(\mathrm{S}_{3}\right)$ & 1.843 & 0.583 & 0.487 & 3.231 & 1.423 & 1.898 & 2.205 \\
Stage Index & 1.973 & 0.513 & 0.554 & 3.127 & 1.691 & 1.990 & 2321 \\
& & & & & & & \\
Top Down Procedures (C1) & 2367 & 0.691 & 0.400 & 4.000 & 2.000 & 2.400 & 2934 \\
Rules and Control (C2) & 1.953 & 0.532 & 0.286 & 3.239 & 1.619 & 1.904 & 2310 \\
Sustainability and Credibility (C3) & 1.780 & 0.724 & 0.190 & 3.333 & 1.309 & 1.762 & 2309 \\
Comprenhensiveness (C4) & 2040 & 0.829 & 0.333 & 3.667 & 1.333 & 2.000 & 2695 \\
$\quad$ Transparency (C5) & 1.854 & 0.639 & 0.375 & 3.250 & 1.500 & 1.750 & 2281 \\
Category Index & 1.999 & 0.532 & 0.469 & 3.123 & 1.641 & 2.004 & 2329 \\
\hline
\end{tabular}

Source: Author's calculations.

Table 3a. Spearman Rank Correlations among Budget Stages

\begin{tabular}{lccc}
\hline & Planning $\left(\mathrm{S}_{1}\right)$ & Approval $\left(\mathrm{S}_{2}\right)$ & Implementation $\left(\mathrm{S}_{3}\right)$ \\
\hline Approval $\left(\mathrm{S}_{2}\right)$ & $0.4357^{*}$ & & \\
Implementation $\left(\mathrm{S}_{3}\right)$ & $0.5822^{*}$ & $0.2077^{n}$ & \\
Stage Index & $0.8493^{*}$ & $0.7097^{*}$ & $0.7334^{*}$ \\
\hline
\end{tabular}

Note: * and " indicate that the correlation coefficient is significantly different from zero at the one percent and ten percent, respectively.

Table 3b. Spearman Rank Correlations among Categories

\begin{tabular}{lccccc}
\hline & $\begin{array}{c}\text { Top Down } \\
\text { Procedures } \\
\left(C_{1}\right)\end{array}$ & $\begin{array}{c}\text { Rules and } \\
\text { Controls } \\
\left(C_{2}\right)\end{array}$ & $\begin{array}{c}\text { Sustainabifity } \\
\text { and } \\
\text { Credibility } \\
\left(C_{3}\right)\end{array}$ & $\begin{array}{c}\text { Comprehensivenes } \\
\text { s }\left(C_{4}\right)\end{array}$ & $\begin{array}{c}\text { Transparency } \\
\left(C_{5}\right)\end{array}$ \\
\hline Rules and Controls $\left(C_{2}\right)$ & $0.3290^{*}$ & & & & \\
Sustainability and Credibility $\left(C_{3}\right)$ & $0.3779^{*}$ & $0.5694^{*}$ & & & \\
Comprehensiveness $\left(C_{4}\right)$ & $0.3954^{*}$ & $0.5596^{*}$ & $0.6203^{*}$ & & \\
Transparency $\left(C_{5}\right)$ & $0.2590^{*}$ & $0.5608^{*}$ & $0.6191^{*}$ & $0.6000^{*}$ & \\
Category Index & $0.5975^{*}$ & $0.7391^{*}$ & $0.8448^{*}$ & $0.8234^{*}$ & $0.7744^{*}$ \\
\hline
\end{tabular}

Note: * indicates that the correlation coefficient is significantly different from zero at the one percent level. 
Figure 2. Budget Institutions, Country Characteristics, and Debt Vulnerabilities in LICs and MICs Budget Insitutions in Low -Income Countries (LICs) and Middle -Income Countries (MICs)

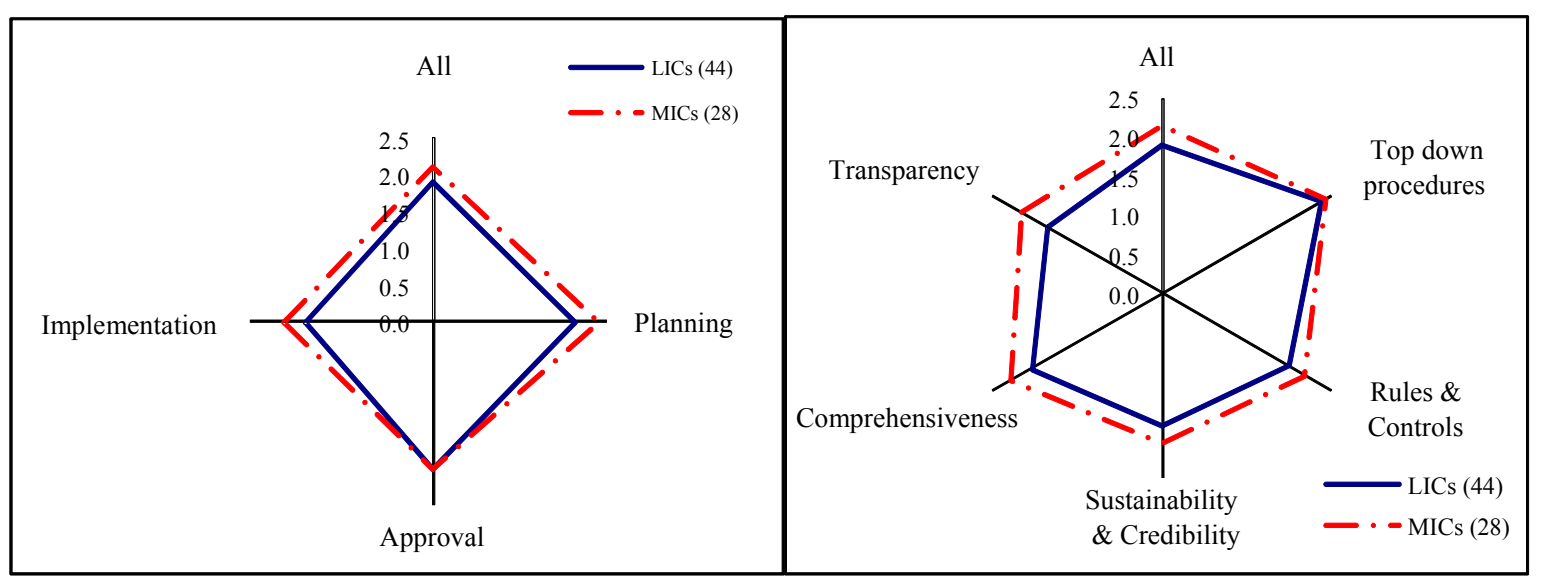

Budget Insitutions in Low Income Countries : Country Characteristics

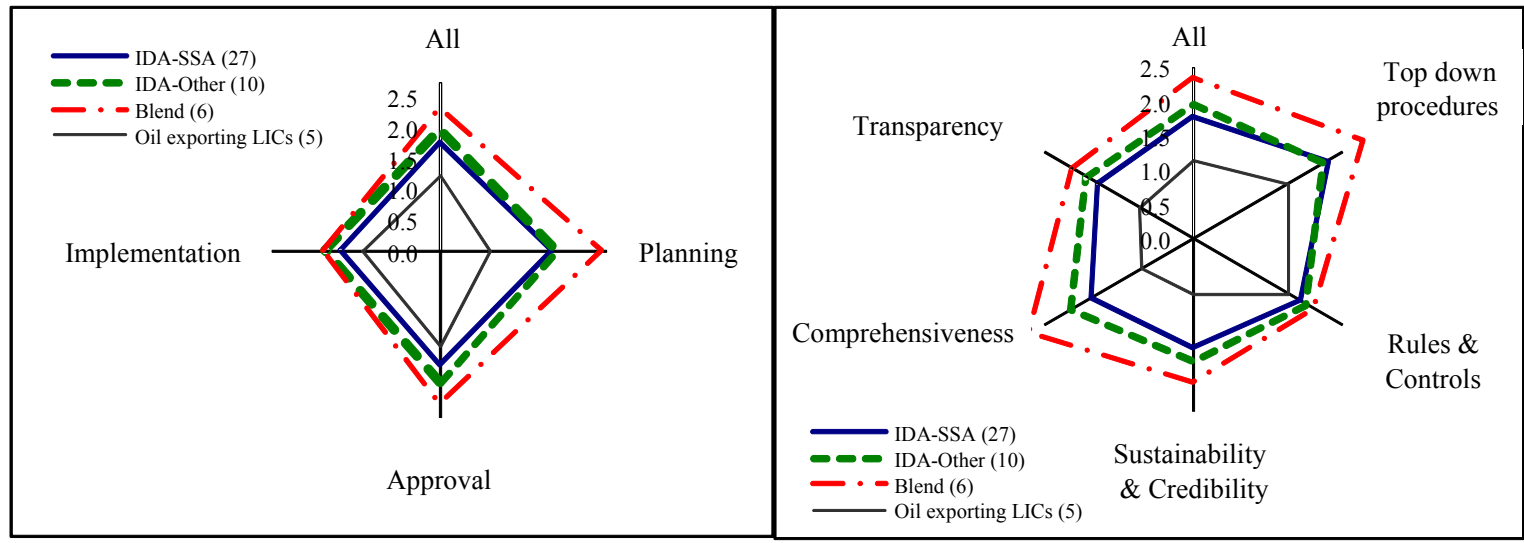

Debt Vulnerabilities in Low Income Countries (LICs)

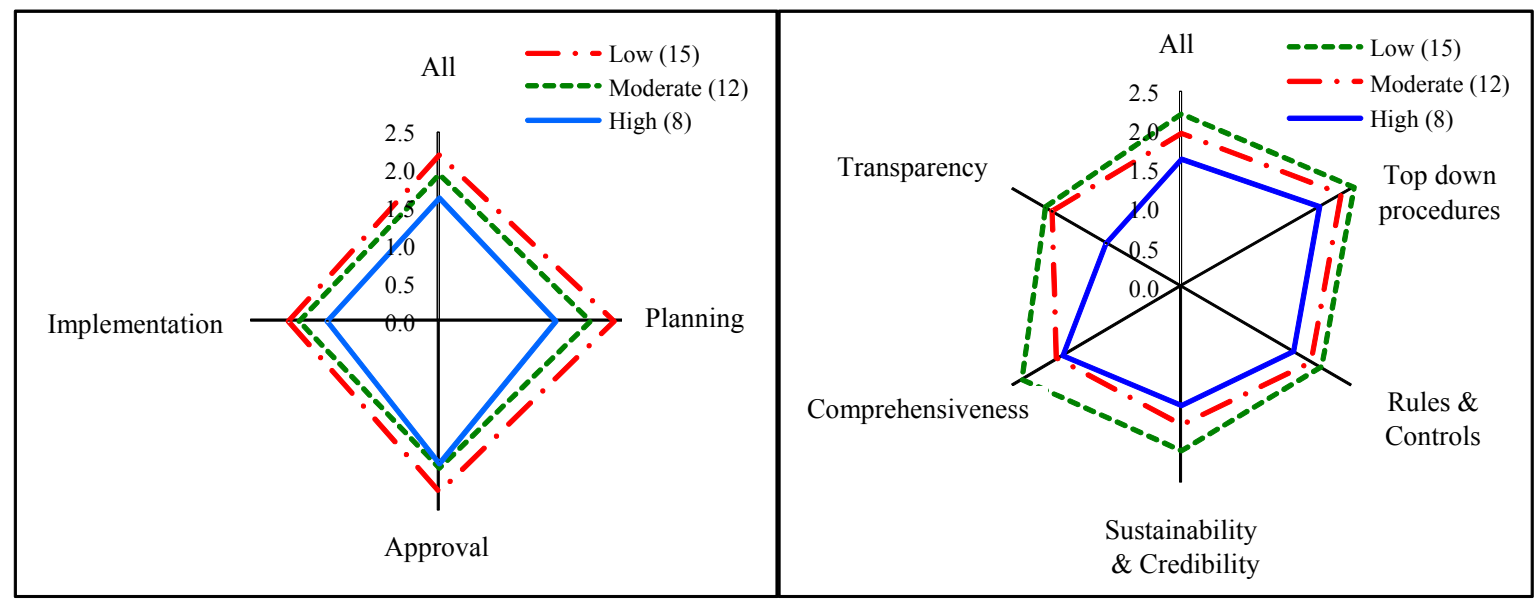

Sources: International Monetary Fund; and staff estimates.

Notes: IDASSA: IDA countries in SußSaharan Africa; IDAOther: IDA countries in other regions;

Blend: Countries eligible for both IDA and IBRD lending; Fuel 
Table 4. Pair-wise Correlations with other Indicators

\begin{tabular}{lccccc}
\hline & PFFA & CPIA & Sub-CPIA & \multicolumn{2}{c}{ Govemance Indicators } \\
\cline { 2 - 6 } & & & & Govemance Effectiveness & Regulatory Quality \\
\hline Stage Index & 0.70 & 0.60 & 0.70 & 0.55 & 0.63 \\
Category Index & 0.76 & 0.65 & 0.73 & 0.62 & 0.69 \\
Number of Observations & 69 & 43 & 43 & 72 & 72 \\
\hline
\end{tabular}

Table 5. Budget Institutions Index, by Country Groups and Stages

Regions

Overall

Budget

Budget

Budget

Planning \& Approval Implementation Negotiation

\begin{tabular}{lllll} 
Sub-Saharan Africa & 1.78 & 1.86 & 1.77 & 1.70 \\
Asia & 1.90 & 1.94 & 1.92 & 1.84 \\
Middle East \& North Africa & 2.14 & 2.29 & 2.33 & 1.79 \\
Latin America \& Caribbean $^{1}$ & 2.14 & 2.15 & 2.11 & 2.17 \\
Transition Economies $^{1}$ & 2.30 & 2.45 & 2.47 & 1.97 \\
& & & & \\
Low Income Countries & 1.89 & 1.95 & 1.99 & 1.73 \\
Middle Income Countries & 2.10 & 2.28 & 2.01 & 2.02 \\
& & & & \\
\hline
\end{tabular}

1/ Includes Albania 
Table 6. Budget Institutions Index, by Country Groups and Categories

\begin{tabular}{|c|c|c|c|c|c|c|}
\hline Regions & Overall & $\begin{array}{l}\text { Top down } \\
\text { Procedures }\end{array}$ & $\begin{array}{l}\text { Rules \& } \\
\text { Controls }\end{array}$ & $\begin{array}{l}\text { Sustainability } \\
\text { \& Credibility }\end{array}$ & Comprehensiveness & Transparency \\
\hline Sub-Saharan Africa & 1.81 & 2.22 & 1.74 & 1.62 & 1.79 & 1.69 \\
\hline Asia & 1.92 & 2.29 & 1.89 & 1.58 & 1.94 & 1.91 \\
\hline Middle East \& North Africa & 2.14 & 2.69 & 2.03 & 1.86 & 2.17 & 1.96 \\
\hline Latin America \& Caribbean & 2.18 & 2.49 & 2.25 & 1.98 & 2.20 & 1.96 \\
\hline Transition Economies ${ }^{1}$ & 2.29 & 2.56 & 2.27 & 2.04 & 2.54 & 2.07 \\
\hline Low Income Countries & 1.91 & 2.35 & 1.87 & 1.69 & 1.92 & 1.70 \\
\hline Middle Income Countries & 2.14 & 2.40 & 2.09 & 1.92 & 2.23 & 2.09 \\
\hline
\end{tabular}

1/ Includes Albania 
Table 7. Budget Institutions, Primary Balance, and External Debt

\begin{tabular}{|c|c|c|c|c|c|c|c|c|}
\hline \multirow[t]{3}{*}{ Dependent Variable: } & \multicolumn{4}{|c|}{ Central Govermment Primary Bahnoe to GDP natio } & \multicolumn{4}{|c|}{ Offioial Publio Extemal Debt to GDP ratio } \\
\hline & \multicolumn{2}{|c|}{ All } & \multirow{2}{*}{$\begin{array}{c}\begin{array}{c}\text { Non-oil } \\
\text { Exporting } \\
\text { only }\end{array} \\
3\end{array}$} & \multirow{2}{*}{$\begin{array}{c}\text { Low-inoome only } \\
\text { (exol. oil- } \\
\text { exporting) }\end{array}$} & \multicolumn{2}{|c|}{ All } & \multirow{2}{*}{$\begin{array}{c}\begin{array}{c}\text { Non-oil } \\
\text { Exporting } \\
\text { only }\end{array} \\
7 \\
\end{array}$} & \multirow{2}{*}{$\begin{array}{c}\text { Low-inoome only } \\
\text { (exol oil } \\
\text { exporting) }\end{array}$} \\
\hline & 1 & 2 & & & 5 & 6 & & \\
\hline Initial_debt & $\begin{array}{c}0.0035 \\
(0.0112)\end{array}$ & $\begin{array}{c}0.0053 \\
(0.0111)\end{array}$ & $\begin{array}{c}0.0065 \\
(0.0129)\end{array}$ & $\begin{array}{c}0.0092 \\
(0.0150)\end{array}$ & $\begin{array}{c}0.5340^{* * *} \\
(0.0807)\end{array}$ & $\begin{array}{c}0.5177^{* * *} \\
(0.0802)\end{array}$ & $\begin{array}{c}0.5712 * * * \\
(0.0851)\end{array}$ & $\begin{array}{c}0.5677^{* * *} \\
(0.1104)\end{array}$ \\
\hline Growth & $\begin{array}{c}-0.2242^{* *} \\
(0.1090)\end{array}$ & $\begin{array}{c}-0.2797^{* *} \\
(0.1083)\end{array}$ & $\begin{array}{c}-0.2609 * \\
(0.1519)\end{array}$ & $\begin{array}{l}-0.1996 \\
(0.2727)\end{array}$ & $\begin{array}{c}0.1392 \\
(0.5988)\end{array}$ & $\begin{array}{c}0.6558 \\
(0.6189)\end{array}$ & $\begin{array}{c}0.6287 \\
(1.2536)\end{array}$ & $\begin{array}{c}1.7735 \\
(1.9136)\end{array}$ \\
\hline Trade & $\begin{array}{l}0.1277^{*} \\
(0.0674)\end{array}$ & $\begin{array}{c}0.1365 * * \\
(0.0633)\end{array}$ & $\begin{array}{c}0.1424 * * \\
(0.0672)\end{array}$ & $\begin{array}{c}0.1699 \\
(0.1099)\end{array}$ & $\begin{array}{l}-0.0198 \\
(0.3733)\end{array}$ & $\begin{array}{l}-0.1020 \\
(0.3090)\end{array}$ & $\begin{array}{c}0.1089 \\
(0.2878)\end{array}$ & $\begin{array}{c}0.0680 \\
(0.3752)\end{array}$ \\
\hline Initial GDP per capita & $\begin{array}{c}0.0024 \\
(0.0042)\end{array}$ & $\begin{array}{c}0.0008 \\
(0.0044)\end{array}$ & $\begin{array}{l}-0.0008 \\
(0.0045)\end{array}$ & $\begin{array}{l}-0.0032 \\
(0.0061)\end{array}$ & $\begin{array}{l}-0.0552 \\
(0.0439)\end{array}$ & $\begin{array}{l}-0.0404 \\
(0.0394)\end{array}$ & $\begin{array}{l}-0.0466 \\
(0.0408)\end{array}$ & $\begin{array}{l}-0.0428 \\
(0.0460)\end{array}$ \\
\hline HIPC & $\begin{array}{c}0.0047 \\
(0.0099)\end{array}$ & $\begin{array}{c}0.0025 \\
(0.0101)\end{array}$ & $\begin{array}{c}0.0023 \\
(0.0093)\end{array}$ & $\begin{array}{c}0.0016 \\
(0.0174)\end{array}$ & $\begin{array}{l}-0.0801 \\
(0.0604)\end{array}$ & $\begin{array}{l}-0.0595 \\
(0.0579)\end{array}$ & $\begin{array}{l}-0.0707 \\
(0.0592)\end{array}$ & $\begin{array}{l}-0.0246 \\
(0.0938)\end{array}$ \\
\hline Oil & $\begin{array}{c}0.0229 \\
(0.0143)\end{array}$ & $\begin{array}{l}0.0269^{*} \\
(0.0141)\end{array}$ & & & $\begin{array}{c}-0.1134 * * \\
(0.0455)\end{array}$ & $\begin{array}{c}-0.1506^{* * * *} \\
(0.0460)\end{array}$ & & \\
\hline Stage Index & & $\begin{array}{l}\text { 0.0098* } \\
(0.0057)\end{array}$ & $\begin{array}{l}0.0107 * \\
(0.0055)\end{array}$ & $\begin{array}{l}0.0171 * \\
(0.0090)\end{array}$ & & $\begin{array}{c}-0.0909 * * * * \\
(0.0303)\end{array}$ & $\begin{array}{c}-0.0770^{* *} \\
(0.0329)\end{array}$ & $\begin{array}{c}-0.0984 * * \\
(0.0457)\end{array}$ \\
\hline $\begin{array}{l}\text { N (Observations) } \\
\text { R Square }\end{array}$ & $\begin{array}{c}65 \\
0.2101\end{array}$ & $\begin{array}{c}65 \\
0.2312\end{array}$ & $\begin{array}{c}56 \\
0.1439\end{array}$ & $\begin{array}{c}34 \\
0.1561\end{array}$ & $\begin{array}{c}65 \\
0.7626\end{array}$ & $\begin{array}{c}65 \\
0.7883\end{array}$ & $\begin{array}{c}56 \\
0.7914\end{array}$ & $\begin{array}{c}34 \\
0.8220\end{array}$ \\
\hline
\end{tabular}

Notes: *: Significant at 10\% level **: Significant at $5 \%$ level ***: Significant at $1 \%$ level Robust standard errors are in parentheses. A constant term was inchuded in all regressions, but is not reported.

Source: IMF staff estimates. 
Table 8. Disaggregated Budget Institutions and Fiscal Performance

\begin{tabular}{|c|c|c|c|c|c|c|c|c|}
\hline & 1 & 2 & 3 & 4 & 5 & 6 & 7 & 8 \\
\hline Phaning & $\begin{array}{c}0.0098^{* *} \\
(0.0039)\end{array}$ & & & & & & & \\
\hline Approval & & $\begin{array}{c}0.0007 \\
(0.0053)\end{array}$ & & & & & & \\
\hline Implementation & & & $\begin{array}{c}0.0069 \\
(0.0052)\end{array}$ & & & & & \\
\hline Top Down Procedures & & & & -0.0033 & & & & \\
\hline & & & & $(0.0047)$ & & & & \\
\hline Rules and Controls & & & & & $\begin{array}{c}0.0062 \\
(0.0061)\end{array}$ & & & \\
\hline Sustainability and Credibility & & & & \multicolumn{5}{|c|}{$\begin{array}{c}0.0058 \\
(0.0043)\end{array}$} \\
\hline Comprehensiveness & & & & & & \multicolumn{3}{|c|}{$\begin{array}{c}0.0082^{* *} \\
(0.0035)\end{array}$} \\
\hline Transpercicy & & & & & & & & $\begin{array}{l}0.0131^{* *} \\
(0.0056)\end{array}$ \\
\hline $\mathbf{N}$ (Observations) & 65 & 65 & 65 & 65 & 65 & 65 & 65 & 65 \\
\hline R Square & 0.2521 & 0.2103 & 0.2227 & 02159 & 0.2209 & 0.2234 & 02509 & 0.2704 \\
\hline
\end{tabular}

Panel B: Dependent Variable: Official Public External Debt (ratio to GDP)

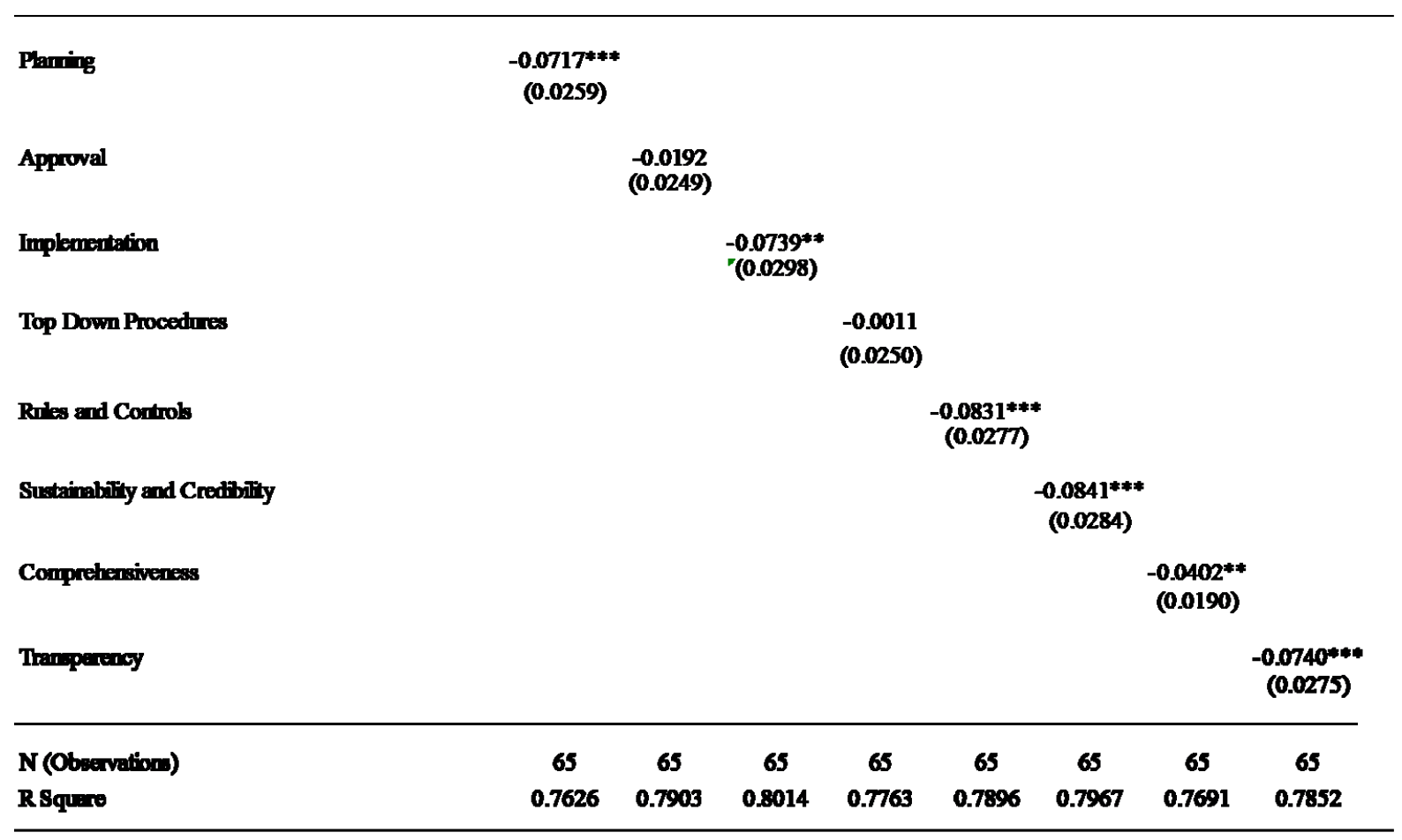

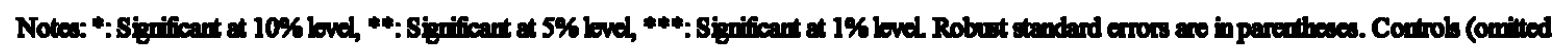
fom table) inchede the fil sat of controls shown in Table 7.

Soucer IMF gtaff estimates. 
Table 9. Budget Institutions and Fiscal Discipline: Robustness Checks

\begin{tabular}{|c|c|c|c|c|c|c|c|}
\hline \multirow[t]{3}{*}{ Dependent variable } & \multicolumn{2}{|c|}{ Primary Balance } & \multicolumn{2}{|c|}{ Official Public External Debt } & \multicolumn{3}{|c|}{$\begin{array}{c}\text { Growth in Official Public Extcrmal Debt } \\
\text { (average anneal) }\end{array}$} \\
\hline & All & Al & All & All & All & $\begin{array}{c}\text { Non-oil } \\
\text { exporting } \\
\text { only }\end{array}$ & $\begin{array}{l}\text { Low-income } \\
\text { only }\end{array}$ \\
\hline & OLS & OLS & OLS & OLS & OLS & OLS & OLS \\
\hline Initial_debt & $\begin{array}{c}0.0054 \\
(0.0112)\end{array}$ & $\begin{array}{c}0.0076 \\
(0.0115)\end{array}$ & $\begin{array}{c}0.5183^{* * *} \\
(0.0807)\end{array}$ & $\begin{array}{c}0.5120 * * * \\
(0.0830)\end{array}$ & $\begin{array}{c}-0.4270^{* *} \\
(0.2034)\end{array}$ & $\begin{array}{c}-0.5189 * * \\
(0.2324)\end{array}$ & $\begin{array}{c}-0.6809 * * \\
(0.2836)\end{array}$ \\
\hline Growth & $\begin{array}{c}-0.2778 * * \\
(0.1095)\end{array}$ & $\begin{array}{c}-0.2516 * * \\
(0.1187)\end{array}$ & $\begin{array}{c}0.6650 \\
(0.6229)\end{array}$ & $\begin{array}{c}0.5886 \\
(0.6184)\end{array}$ & $\begin{array}{c}0.5554 \\
(1.9334)\end{array}$ & $\begin{array}{c}2.3054 \\
(3.4186)\end{array}$ & $\begin{array}{c}2.2687 \\
(3.9329)\end{array}$ \\
\hline Trade & $\begin{array}{l}0.1311 * * \\
(0.0647)\end{array}$ & $\begin{array}{l}0.1225 * \\
(0.0638)\end{array}$ & $\begin{array}{l}-0.1278 \\
(0.3285)\end{array}$ & $\begin{array}{l}-0.0685 \\
(0.3160)\end{array}$ & $\begin{array}{c}0.5372 \\
(0.5268)\end{array}$ & $\begin{array}{c}0.4719 \\
(0.6018)\end{array}$ & $\begin{array}{c}1.0876 \\
(0.8757)\end{array}$ \\
\hline Intial GDP per capita & $\begin{array}{c}0.0023 \\
(0.0056)\end{array}$ & $\begin{array}{l}-0.0002 \\
(0.0046)\end{array}$ & $\begin{array}{l}-0.0332 \\
(0.0455)\end{array}$ & $\begin{array}{l}-0.0380 \\
(0.0392)\end{array}$ & $\begin{array}{c}-0.2770^{*} * \\
(0.1376)\end{array}$ & $\begin{array}{c}-0.2731 * * \\
(0.1314)\end{array}$ & $\begin{array}{c}-0.3545^{* *} \\
(0.1401)\end{array}$ \\
\hline HIPC & $\begin{array}{c}0.0031 \\
(0.0103)\end{array}$ & $\begin{array}{c}0.0045 \\
(0.0102)\end{array}$ & $\begin{array}{l}-0.0564 \\
(0.0602)\end{array}$ & $\begin{array}{l}-0.0645 \\
(0.0577)\end{array}$ & $\begin{array}{c}-0.2804 * * \\
(0.1398)\end{array}$ & $\begin{array}{c}-0.2632^{*} \\
(0.1349)\end{array}$ & $\begin{array}{l}-0.2177 \\
(0.1811)\end{array}$ \\
\hline Oil & $\begin{array}{l}0.0255^{*} \\
(0.0142)\end{array}$ & $\begin{array}{l}0.0275^{*} \\
(0.0141)\end{array}$ & $\begin{array}{c}-0.1568^{* * *} \\
(0.0494)\end{array}$ & $\begin{array}{c}-0.1520^{* * *} \\
(0.0467)\end{array}$ & $\begin{array}{c}-0.1396^{*} \\
(0.0813)\end{array}$ & & $\begin{array}{c}-0.2939 * \\
(0.1574)\end{array}$ \\
\hline Private Credit & $\begin{array}{l}-0.0001 \\
(0.0002)\end{array}$ & & $\begin{array}{l}-0.0004 \\
(0.0007)\end{array}$ & & & & \\
\hline IMF program & & $\begin{array}{l}-0.0089 \\
(0.0079)\end{array}$ & & $\begin{array}{c}0.0214 \\
(0.0309)\end{array}$ & & & \\
\hline Stage Index & $\begin{array}{l}0.0098 * \\
(0.0057)\end{array}$ & $\begin{array}{l}0.0111 * \\
(0.0063)\end{array}$ & $\begin{array}{c}-0.0909 * * * \\
(0.0305)\end{array}$ & $\begin{array}{c}-0.0941 * * * \\
(0.0320)\end{array}$ & $\begin{array}{c}-0.1795 * * \\
(0.0800)\end{array}$ & $\begin{array}{c}-0.2047 * * \\
(0.0877)\end{array}$ & $\begin{array}{c}-0.2135^{* *} \\
(0.0931)\end{array}$ \\
\hline $\begin{array}{l}\text { N (Observations) } \\
\text { R Square }\end{array}$ & $\begin{array}{c}65 \\
0.2347\end{array}$ & $\begin{array}{c}65 \\
0.2440\end{array}$ & $\begin{array}{c}65 \\
0.7894\end{array}$ & $\begin{array}{c}65 \\
0.7893\end{array}$ & $\begin{array}{c}65 \\
0.4139\end{array}$ & $\begin{array}{c}56 \\
0.4372\end{array}$ & $\begin{array}{c}39 \\
0.5530\end{array}$ \\
\hline
\end{tabular}

Notes: *: Significant at $10 \%$ level, **: Significant at $5 \%$ level, ***: Significant at $1 \%$ level Robust standard errors are in parentheses. A constant term was included in all regressions, but is not reported.

Source: IMF staff estimates. 
Table 10. Robustness Checks: Role of Economy-wide Institutions

\begin{tabular}{|c|c|c|c|c|c|c|}
\hline \multirow[b]{2}{*}{ Initial_debt } & \multicolumn{2}{|c|}{ Primary Balance } & \multicolumn{2}{|c|}{ External debt } & \multicolumn{2}{|c|}{ External Debt Growth } \\
\hline & $\begin{array}{l}0.0044 \\
(0.0105)\end{array}$ & $\begin{array}{l}0.0042 \\
(0.0104)\end{array}$ & $\begin{array}{l}0.5100^{* * *} \\
(0.0837)\end{array}$ & $\begin{array}{l}0.5074 * * * \\
(0.0819)\end{array}$ & $\begin{array}{l}-0.4713^{* *} \\
(0.2184)\end{array}$ & $\begin{array}{l}-0.4702 * * \\
(0.2179)\end{array}$ \\
\hline Growth & $\begin{array}{l}-0.2698^{* *} \\
(0.1074)\end{array}$ & $\begin{array}{l}-0.2630^{* *} \\
(0.1061)\end{array}$ & $\begin{array}{l}0.5149 \\
(0.6780)\end{array}$ & $\begin{array}{l}0.7498 \\
(0.6613)\end{array}$ & $\begin{array}{l}0.8618 \\
(1.8984)\end{array}$ & $\begin{array}{l}0.6881 * \\
(1.9412)\end{array}$ \\
\hline Trade & $\begin{array}{l}0.1429 * * \\
(0.0651)\end{array}$ & $\begin{array}{l}0.1420 * * \\
(0.0630)\end{array}$ & $\begin{array}{l}-0.1076 \\
(0.3374)\end{array}$ & $\begin{array}{l}-0.1399 \\
(0.3398)\end{array}$ & $\begin{array}{l}0.4363 \\
(0.4875)\end{array}$ & $\begin{array}{l}0.4602 \\
(0.4893)\end{array}$ \\
\hline Initial GDP per capita & $\begin{array}{l}0.0027 \\
(0.0054)\end{array}$ & $\begin{array}{l}0.0039 \\
(0.0064)\end{array}$ & $\begin{array}{l}-0.0193 \\
(0.0376)\end{array}$ & $\begin{array}{l}0.0005 \\
(0.0484)\end{array}$ & $\begin{array}{l}-0.2790^{* *} \\
(0.1274)\end{array}$ & $\begin{array}{l}-0.2802 \\
(0.1411)\end{array}$ \\
\hline HIPC & $\begin{array}{l}0.0100 \\
(0.0123)\end{array}$ & $\begin{array}{l}0.0110 \\
(0.0119)\end{array}$ & $\begin{array}{l}-0.0466 \\
(0.0544)\end{array}$ & $\begin{array}{l}-0.0323 \\
(0.0587)\end{array}$ & $\begin{array}{l}-0.2875^{* *} \\
(0.1231)\end{array}$ & $\begin{array}{l}-0.2852 * * \\
(0.1349)\end{array}$ \\
\hline Oil & $\begin{array}{l}0.0262 * \\
(0.0147)\end{array}$ & $\begin{array}{l}0.0255^{*} \\
(0.0151)\end{array}$ & $\begin{array}{l}-0.1784^{* * *} \\
(0.0531)\end{array}$ & $\begin{array}{l}-0.1862 * * * \\
(0.0547)\end{array}$ & $\begin{array}{l}-0.1832 * \\
(0.1038)\end{array}$ & $\begin{array}{l}-0.1863^{*} \\
(0.0980)\end{array}$ \\
\hline Control of Corruption & $\begin{array}{l}-0.0011 \\
(0.0081)\end{array}$ & & $\begin{array}{l}-0.0494 \\
(0.0419)\end{array}$ & & $\begin{array}{l}0.0435 \\
(0.0599)\end{array}$ & \\
\hline Government Effectiveness & & $\begin{array}{l}-0.0032 \\
(0.0095)\end{array}$ & & $\begin{array}{l}-0.0766 \\
(0.0587)\end{array}$ & & $\begin{array}{l}0.0366 \\
(0.0832)\end{array}$ \\
\hline Stage Index & $\begin{array}{l}0.0099 * \\
(0.0059)\end{array}$ & $\begin{array}{l}0.0105^{*} \\
(0.0061)\end{array}$ & $\begin{array}{l}-0.0785^{* *} \\
(0.0313)\end{array}$ & $\begin{array}{l}-0.0712 * * \\
(0.0347)\end{array}$ & $\begin{array}{l}-0.2124^{* *} \\
(0.0858)\end{array}$ & $\begin{array}{l}-0.2095 * * \\
(0.0924)\end{array}$ \\
\hline $\begin{array}{l}\text { N (Observations) } \\
\text { R Square }\end{array}$ & $\begin{array}{c}65 \\
0.2428\end{array}$ & $\begin{array}{c}65 \\
0.2438\end{array}$ & $\begin{array}{c}65 \\
0.7987\end{array}$ & $\begin{array}{c}65 \\
0.8022\end{array}$ & $\begin{array}{c}65 \\
0.4208\end{array}$ & $\begin{array}{c}65 \\
0.4192\end{array}$ \\
\hline
\end{tabular}

Notes: *: Significant at 10\% level, **: Significant at 5\% level, ***: Significant at $1 \%$ level. Robust standard errors are in parentheses. A constant term was included in all regressions, but is not reported. 
Table 11. Budget Institutions, Fiscal Accommodation, and the Global Crisis, 2008-09

\begin{tabular}{|c|c|c|c|c|}
\hline \multirow[t]{2}{*}{ Dependent Variable: } & \multicolumn{2}{|c|}{$\begin{array}{c}\text { Change in Central } \\
\text { Government Primary } \\
\text { Balance }\end{array}$} & \multicolumn{2}{|c|}{$\begin{array}{l}\text { Change in Central } \\
\text { Government Expenditure }\end{array}$} \\
\hline & 1 & 2 & 3 & 4 \\
\hline Primary Balance (lagged) & $\begin{array}{l}-5.0120 \\
(8.1787)\end{array}$ & $\begin{array}{l}-5.2138 \\
(8.4038)\end{array}$ & $\begin{array}{l}0.6002^{*} \\
(0.3138)\end{array}$ & $\begin{array}{l}0.6073^{*} \\
(0.3222)\end{array}$ \\
\hline Oil & $\begin{array}{c}0.4113 \\
(1.1898)\end{array}$ & $\begin{array}{c}0.1642 \\
(1.0113)\end{array}$ & $\begin{array}{c}-0.1868^{* *} \\
(0.0696)\end{array}$ & $\begin{array}{c}-0.1782^{* *} \\
(0.0638)\end{array}$ \\
\hline External Debt (lagged) & $\begin{array}{l}-0.5585 \\
(1.8197)\end{array}$ & $\begin{array}{l}-0.9132 \\
(1.9283)\end{array}$ & $\begin{array}{c}0.0456 \\
(0.0757)\end{array}$ & $\begin{array}{c}0.0580 \\
(0.0777)\end{array}$ \\
\hline Growth & $\begin{array}{c}-0.2487^{* *} \\
(0.1207)\end{array}$ & $\begin{array}{c}-0.2443^{* *} \\
(0.1219)\end{array}$ & $\begin{array}{c}0.0018 \\
(0.0038)\end{array}$ & $\begin{array}{c}0.0017 \\
(0.0035)\end{array}$ \\
\hline Log GDP per Capita & $\begin{array}{l}-1.6209 \\
(1.0706)\end{array}$ & $\begin{array}{l}-1.5517 \\
(1.0231)\end{array}$ & $\begin{array}{l}-0.0085 \\
(0.0216)\end{array}$ & $\begin{array}{l}-0.0109 \\
(0.0220)\end{array}$ \\
\hline Overall Stages Index & & $\begin{array}{c}-1.5629 * \\
(0.8907)\end{array}$ & & $\begin{array}{c}0.0545^{* *} \\
(0.0269)\end{array}$ \\
\hline $\begin{array}{l}\mathrm{N} \text { (Observations) } \\
\mathrm{R} \text { Square }\end{array}$ & $\begin{array}{c}62 \\
0.1023\end{array}$ & $\begin{array}{c}62 \\
0.1337\end{array}$ & $\begin{array}{c}62 \\
0.2378\end{array}$ & $\begin{array}{c}62 \\
0.2842\end{array}$ \\
\hline
\end{tabular}

Notes: *: Significant at $10 \%$ level, **: Significant at $5 \%$ level, ***: Significant at $1 \%$ level. Robust standard errors are in parentheses. A constant term was included in all regressions, 
Table 12. Budget Institutions, Impact on Procyclicality

Dependent Variable: Growth in central government expenditures

Two-step Difference-GMM estimates

\begin{tabular}{|c|c|c|c|c|c|}
\hline & Above Median Group & Observations & Below Median Group & Observations & Median Threshold \\
\hline \multirow[t]{2}{*}{ Overall Index } & $0.55^{*}$ & 263 & $1.47^{* *}$ & 237 & 2.01 \\
\hline & $(0.29)$ & & $(0.72)$ & & \\
\hline \multirow[t]{2}{*}{ Planning } & $0.60^{*}$ & 263 & $1.40^{*}$ & 237 & 2.14 \\
\hline & $(0.35)$ & & $(0.79)$ & & \\
\hline \multirow[t]{2}{*}{ Approval } & 0.40 & 263 & $0.89 * *$ & 237 & 2.11 \\
\hline & $(0.51)$ & & $(0.43)$ & & \\
\hline \multirow[t]{2}{*}{ Implementation } & 0.62 & 191 & 1.05 & 253 & 2.11 \\
\hline & $(0.52)$ & & $(0.64)$ & & \\
\hline \multirow[t]{2}{*}{ Top-Down Procedures } & 0.52 & 207 & 0.76 & 261 & 2.4 \\
\hline & $(0.45)$ & & $(0.50)$ & & \\
\hline \multirow[t]{2}{*}{ Rules and Control } & 0.69 & 247 & 0.90 & 205 & 1.90 \\
\hline & $(0.50)$ & & $(0.72)$ & & \\
\hline \multirow[t]{2}{*}{ Sustainability and Credbility } & 0.49 & 255 & 0.53 & 245 & 1.80 \\
\hline & $(0.35)$ & & $(0.42)$ & & \\
\hline \multirow[t]{2}{*}{ Comprehensiveness } & $0.73^{* *}$ & 244 & 0.52 & 192 & 2.00 \\
\hline & $(0.35)$ & & $(0.70)$ & & \\
\hline \multirow[t]{2}{*}{ Transparency } & $0.84^{*}$ & 256 & 1.78 & 188 & 1.75 \\
\hline & $(0.45)$ & & (1.16) & & \\
\hline
\end{tabular}

Notes: *: Significant at 10\% level; **: Significant at 5\% level; ***: Significant at $1 \%$ level. The reported estimated standard errors, using Windmejer (2005)'s fnite sample correction, ane in parentheses. Al regressions include a control for terms of trade growth and hgged growth in central government spending. GDP growth and the lagged dependent varible are instrumented for using lags. See appendix for variable description. 
Table 13. Budget Institutions, Income and Debt, Combined Impact on Procyclicality Dependent Variable: Growth in central government expenditures

Two-step Difference-GMM Estimates

\begin{tabular}{lccccc}
\hline \multirow{2}{*}{ Overall Indexes } & \multicolumn{2}{c}{ Low-Income Countries } & & \multicolumn{2}{c}{ Debt } \\
\cline { 2 - 3 } \cline { 5 - 6 } \cline { 5 - 6 } & Above Median Group & Below Median Group & & Above Median Group & Bebw Median Group \\
\hline Overall Index & $1.10^{* *}$ & $3.85^{*}$ & & 0.29 & $1.61^{* *}$ \\
Plaming & $(0.48)$ & $(2.16)$ & & $(0.61)$ & $(0.79)$ \\
Approval & $0.91^{* *}$ & $3.27^{* *}$ & & 0.52 & 1.53 \\
& $(0.44)$ & $(1.37)$ & & $(1.26)$ & $(1.02)$ \\
Implementation & 0.68 & $5.27^{* *}$ & & 0.33 & 1.18 \\
& $(0.79)$ & $(3.09)$ & & $(0.47)$ & $(0.82)$ \\
Top-Down Procedures & 1.15 & $2.86^{* *}$ & & 1.05 & 2.09 \\
& $(1.02)$ & $(1.34)$ & & $(0.89)$ & $(1.29)$ \\
Rules and Control & $1.29^{* *}$ & 0.77 & & -0.19 & 1.59 \\
& $(0.60)$ & $(0.62)$ & & $(0.78)$ & $(1.11)$ \\
Sustainability and Credbility & 1.13 & 2.89 & & 0.87 & 0.68 \\
& $(0.76)$ & $(2.9)$ & & $(1.47)$ & $(0.78)$ \\
Comprehensiveness & 0.83 & 1.60 & & 0.61 & 0.53 \\
& $(0.61)$ & $(2.09)$ & & $(0.97)$ & $(0.68)$ \\
Transparency & $1.20^{* *}$ & $2.31^{* * *}$ & & 0.34 & 0.82 \\
& $(0.49)$ & $(0.82)$ & & $(0.98)$ & $(0.83)$ \\
& $1.29^{* *}$ & 2.44 & & 0.56 & $2.41^{*}$ \\
& $(0.51)$ & $(2.50)$ & $0.70)$ & $(1.13)$ \\
\hline
\end{tabular}

Notes: *: Significant at $10 \%$ bvel **: Significant at $5 \%$ level; ***: Significant at $1 \%$ level The reported estimated standard errors, using Windmeijer (2005)'s finite sample correction, are in parentheses. All regressions include a control for terms of trade growth and lagged growth in central govermment spending. GDP growth and the lagged dependent variable are instrumented for using lags. See appendix for variable description. 


\section{References}

Aguiar, Mark and Gita Gopinath, 2007, Emerging Market Business Cycles: The Cycle is the Trend, Journal of Political Economy, Vol. 115 (1), pp. 69-102.

Akitoby, Bernardin, Benedict J. Clements, Sanjeev Gupta, and Gabriela Inchauste, 2006, Public Spending, Voracity, and Wagner's Law in Developing Countries," European Journal of Political Economy, Vol. 22 (1), pp. 908-24.

Alberola, Enrique and Jose Montero, 2006, "Debt Sustainability and Procyclical Fiscal Policies in Latin America,” Banco de Espana Working Paper No. 0611 (Madrid: Banco de Espana).

Alesina, Alberto, Felipe R. Campante, and Guido Tabellini, 2008, "Why is Fiscal Policy Often Procyclical?" Journal of the European Economic Association, Vol. 6 (7) (September), pp. 1006-36.

Alesina, Alberto and Roberto Perotti, 1999, "Budget Deficits and Budget Institutions," NBER Chapters, Fiscal Institutions and Fiscal Performance, pp. 13-36.

Alesina, Alberto, Ricardo Hausmann, Rudolf Hommes, and Ernesto Stein, 1999, "Budget Institutions and Fiscal Performance in Latin America," Journal of Development Economics, Vol. 59, pp. 253-73.

Allen, Richard, 2009, "The Challenge of Reforming Budgetary Institutions in Developing Countries,” IMF Working Paper 09/96 (Washington: International Monetary Fund).

Allen, Richard and Dimitar Radev, 2006, "Managing and Controlling Extrabudgetary Funds," OECD Journal on Budgeting, Vol. 6, No. 4 (August), pp. 1403-1439.

Alt, James and David Lassen, 2006, "Fiscal Transparency, Political Parties, and Debt in OECD Countries," European Economic Review, Vol. 50 (6), pp. 1401-1439.

Arcand, Jean-Louis and Marcel Dagenais, 2005, "Errors in Variables and the Empirics of Economic Growth,” CERDI Working Paper No. 200536 (CERDI: Geneva, Switzerland).

Balassone, Fabrizio and Manmohan Kumar, 2007, "Cyclicality of Fiscal Policy," Promoting Fiscal Discipline, (eds.) Manmohan S. Kumar and Teresa Ter-Minassian (Washington: International Monetary Fund).

Beetsma, Roel, Massimo Giuliodori, and Peter Wierts, 2009, "Planning to Cheat: EU Fiscal Policy in Real Time," Economic Policy, Vol. 24, No. 60 (October), pp. 753-804. 
Campos, Edward and Sanjay Pradhan, 1996, "Budgetary Institutions and Expenditure Outcomes: Binding Governments to Fiscal Performance," Policy Research Working Paper No. 1646 (Washington: World Bank).

Diallo, Oumar, 2009, "Tortuous Road Toward Countercyclical Fiscal Policy: Lessons from Democratized Sub-Saharan Africa,” Journal of Policy Modeling, Vol. 31 (January), pp. 36-50.

Dixit, Avinash, 1998, The Making of Economic Policy: a Transaction Cost Politics Perspective. (Cambridge, Massachusetts: MIT Press).

Fabrizio, Stefania and Ashoka Mody, 2006, "Can Budget Institutions Counteract Political Indiscipline? Economic Policy, CEPR, CES, MSH, vol. 21(48), pp 689-739,

Filc, Gabriel, and Carlos Scartascini, 2005, "Budget Institutions and Fiscal Outcomes: Ten Years of Inquiry on Fiscal Matters at the Research Department of the Inter-American Development Bank," International Journal of Public Budget, Vol. 59 (December), pp. 81-138.

Filc, Gabriel and Carlos Scartascini, 2007, "Budgetary institutions," in E. Lora (ed.) The State of State Reform in Latin America (Washington DC: Stanford University Press).

Gavin, Michael and Roberto Perotti, 1997, "Fiscal Policy in Latin America," NBER Macroeconomic Annual, (Cambridge, Massachusetts: MIT Press) pp. 11-71.

Gupta, Sanjeev, Gerd Schwartz, Shamsuddin Tareq, Richard Allen, Isabell Adenauer, Kevin Fletcher, and Duncan Last, 2008, "Fiscal Management of Scaled-Up Aid," (Washington: International Monetary Fund).

Hallerberg, Mark and Guntram Wolff, 2008, "Fiscal Institutions, Fiscal Policy and Sovereign Risk Premia in EMU," Public Choice, Vol. 136, Issue 3, pp. 379-396.

Hallerberg, Mark and Jürgen von Hagen, 1999, "Electoral Institutions, Cabinet Negotiations, and Budget Deficits within the European Union," in James Poterba and Jürgen von Hagen (eds.) Fiscal Institutions and Fiscal Performance, (Chicago: University of Chicago Press), pp. 209-32.

Hallerberg, Mark, Rolf Strauch, and Jürgen von Hagen, 2004, "The Design of Fiscal Rules and Forms of Governance in European Union Countries," ECB Working Paper No. 419 (European Central Bank: Frankfurt). 
Hameed, Farhan, 2005, "Fiscal Transparency and Economic Outcomes," IMF Working Paper 05/225, (Washington: International Monetary Fund).

von Hagen, Jürgen, 1992, "Budgeting Procedures and Fiscal Performance in the European Communities," European Economy - Economic Papers, Vol. 96. Commission of the EC, Directorate-General for Economic and Financial Affairs (DG ECFIN).

von Hagen, Jürgen and Ian harden, 1994, "National Budget Processes and Fiscal Performance," European Economy Reports and Studies, Vol. 3, pp. 311-418.

von Hagen, Jürgen and Ian harden, 1996, "Budget Processes and Commitment to Fiscal Discipline," IMF Working Paper 96/78 (Washington: International Monetary Fund).

Ilzetzki, Ethan and Carlos A. Vegh, 2008, "Procyclical Fiscal Policy in Developing Countries: Truth or Fiction?” NBER Working Papers 14191, National Bureau of Economic Research.

International Monetary Fund, 2010, "Fiscal Consolidation in the G-20: The Role of Budget Institutions" (forthcoming; Washington: International Monetary Fund).

International Monetary Fund, 2009a, "Fiscal Rules-Anchoring Expectations for Sustainable Public Finances" (Washington: International Monetary Fund).

International Monetary Fund, 2009b, Regional Economic Outlook: Sub-Saharan Africa, October 2009 (Washington).

International Monetary Fund, 2007, World Economic Outlook, April 2007, (Washington).

Kaminsky, Graciela, Carmen Reinhart, and Carlos Végh, 2004, "When It Rains, It Pours: Procyclical Capital Flows and Macroeconomic Policies," NBER Macroeconomics, Annual, (eds.) Kenneth Rogoff and Mark Gertler (Cambridge, Massachusetts: MIT Press).

Kopits, George and Jon Craig, 1998, "Transparency in Government Operations," IMF Occasional Paper 158, (Washington: International Monetary Fund).

Le Houerou, Phillipe and Robert Taliercio, 2002, "Medium Term Expenditure Frameworks: From Concept to Practice. Preliminary Lessons from Africa," Africa Region Working Paper Series No. 28 (Washington: World Bank). 
Lledo, Victor, Irene Yackolev, and Lucie Gadenne, 2009, "Cyclical Patterns of Government Expenditures in Sub-Saharan Africa: Facts and Factors," IMF Working Paper 09/274 (Washington: International Monetary Fund).

Ljungman, Gösta, 2009, “Top-Down Budgeting - An Instrument to Strengthen Budget Management,” IMF Working Paper 09/243 (Washington: International Monetary Fund).

Manasse, Paolo, 2006, "Procyclical Fiscal Policy: Shocks, Rules, and Institutions: A View from MARS,” IMF Working Paper 06/27 (Washington: International Monetary Fund).

Mulas-Granados, Carlos, Jorge Onrubia, and Javier Salinas-Jeménez, 2009, "Do Budget Institutions Matter? Fiscal Consolidation in the New EU Member States," Eastern European Economics, Vol. 47 (1), pp. 60-91.

Perotti, Roberto, and Yianos Kontopoulos, 2002, "Fragmented Fiscal Policy," Journal of Public Economics, Elsevier, Vol. 86 (2), pp. 191-222.

Persson, Torsten and Guido Tabellini, 2005, Economic Effects of Constitutions (Cambridge, Massachusetts: MIT Press).

Persson, Torsten, Gerard Roland, Guido Tabellini, 2000, "Comparative Politics and Public Finance,” Journal of Political Economy, Vol. 108 (6) (March), pp. 1121-1161.

Poterba, James and Jürgen von Hagen, 1999, Fiscal Institutions and Fiscal Performance (Chicago: University of Chicago Press).

Prakash, Tej and Cabezon Ezequiel, 2008, "Public Financial Management and Fiscal Outcomes in Sub-Saharan African Heavily-Indebted Poor Countries," IMF Working Paper 08/217 (Washington: International Monetary Fund).

Schiavo-Campo, Salvatore, 2009, "Potemkin Villages: The Medium-Term Expenditure Framework in Developing Countries," Public Budgeting and Finance, Vol. 29, Issue 2, (June), pp. 1-26.

Schick, Allen, 1998, "Why Most Developing Countries Should Not Try New Zealand Reforms," The World Bank Research Observer, Vol. 13, No. 1 (February), pp. 123-131.

Shepsle, Kenneth and Barry Weingast, 1981, "Political Preferences for the Pork Barrel: A Generalization," American Journal of Political Science, Vol. 25 (1): 96-111.

Talvi, Ernesto and Carlos Végh, 2005, "Tax Base Variability and Procyclical Fiscal Policy in Developing Countries," Journal of Development Economics, Vol. 78, pp. 156-90. 
Thornton, John, 2008, "Explaining Procyclical Fiscal Policy in African Countries," Journal of African Economies, Vol. 17, No. 3, pp. 451-64.

Tornell, Aaron and Philip Lane, 1999, "The Voracity Effect," American Economic Review, Vol.89, No. 1 (March), pp. 22-46.

Velasco, Andres, 1999, “A Model of Endogenous Fiscal Deficits and Delayed Fiscal Reforms," NBER Chapters, Fiscal Institutions and Fiscal Performance, pp. 37-58.

Weingast, Barry, Kenneth Shepsle, and Christopher Johnsen, 1981, "The Political Economy of Benefits and Costs: A Neoclassical Approach to Distributive Politics," Journal of Political Economy, Vol. 89 (4): 642-64. 


\section{Appendix I. Data Sources Used}

The data used in this study draw on the following main sources:

Public Expenditure and Financial Accountability (PEFA) assessments. The PEFA framework was developed between 2003 and 2005 as a joint undertaking of the World Bank, the European Commission, the UK's Department for International Development (DFID), the Swiss State Secretariat for Economic Affairs, the Royal Norwegian Ministry of Foreign Affairs, the French Ministry of Foreign Affairs, and the IMF. Since 2005, the PEFA program conducts assessments, some of which are publicly available in the form of country reports, on the technical and institutional basis for sound budget governance covering a broad range of PFM performance indicators. It uses 28 indicators grouped in three areas: credibility of the budget; comprehensiveness and transparency and budget cycle. PEFA assessments are done every three years and cover 96 countries.

OECD International Budget Practices and Procedures Database. The database, which was originally developed by the OECD, contains the results of the 2007 OECD survey of budget practices and procedures in OECD countries, the 2008 World Bank/OECD survey of budget practices and procedures in Asia and other regions, and the $2008 \mathrm{CABRI} / \mathrm{OECD}$ survey of budget practices and procedures in Africa. The database contains the results of surveys for the 30 OECD member countries and 67 developing countries from Africa, the Middle East, Eastern Europe, Asia, Latin America and the Caribbean. Questions cover most of the stages and several aspects of the budget cycle, including preparation, approval, execution, accounting and audit, and performance information. The questions are of the multiple-choice or check-the-box type.

IBP Open Budget Index. The International Budget Partnership, part of the Washingtonbased NGO Center on Budget and Policy Priorities, publishes the IBP Open Budget Index. The index provides extensive data and rankings on the level of transparency of the budget process in 85 developed and developing countries based on surveys conducted by local civil society partners. The questions reflecting the quantity and quality of publicly available budget information in eight key documents associated with the following four stages of the budget process: formulation, approval, execution, and evaluation/audit.

Reports of the Observance of Standards and Codes (ROSCS). In 1998, the IMF Board adopted the Code of Good Practices and Fiscal Transparency, which was updated in 2007. It involves standards and codes on the budget process including the clarity of roles and responsibility; public availability of information; open budget preparation, execution and reporting; and assurances of integrity. Since then, the World Bank and the IMF have completed ROSCS for 86 developed and developing countries. 
Appendix II. Dimensions, Scoring Methodology, and Sources of Data

\begin{tabular}{|c|c|c|}
\hline $\begin{array}{l}\text { Dimensions and } \\
\text { Categories }\end{array}$ & Definition/Score Methodology & Sources \\
\hline \multicolumn{3}{|c|}{ I. Budget Planning and Negotiation } \\
\hline \multicolumn{3}{|l|}{ Top-down Budgeting } \\
\hline $\begin{array}{l}\text { Fragmentation of } \\
\text { budgetary authority }\end{array}$ & $\begin{array}{l}\text { The score is } 0 \text { if there are several ministries or governmental bodies; and } 4 \text { if } \\
\text { MoF or another single CBA has primary responsibility for managing the budget. }\end{array}$ & $\begin{array}{l}\text { OECD, FAD } \\
\text { economists, and } \\
\text { ROSC }\end{array}$ \\
\hline $\begin{array}{l}\text { Agenda setting (top- } \\
\text { down budgeting) }\end{array}$ & $\begin{array}{l}\text { The score is } 0 \text { if there are no ex ante limits on ministerial budget submissions } \\
\text { before the discussion of sectoral/ministerial budgets; } 1.33 \text { if there are ex ante } \\
\text { limits but cabinet does not play a role; } 2.67 \text { if there are exante limits but } \\
\text { influence of the cabinet is limited and } 4 \text { if there are ex ante limits on ministerial } \\
\text { budget submissions and prior approval by Cabinet. }\end{array}$ & $\begin{array}{l}\text { OECD, PEFA } \\
\text { reports, and } \\
\text { OECD }\end{array}$ \\
\hline \multicolumn{3}{|l|}{ Rules and Controls } \\
\hline $\begin{array}{l}\text { Numerical fiscal } \\
\text { rules codified in law }\end{array}$ & $\begin{array}{l}\text { The score is } 0 \text { if there are no fiscal targets or objectives; } 2 \text { if there are fiscal } \\
\text { targets or objectives but not codified by law; and } 4 \text { if there are fiscal targets } \\
\text { codified in law. }\end{array}$ & $\begin{array}{l}\text { OECD, } \\
\text { ROSC, FAD } \\
\text { economists, } \\
\text { and IMF } \\
\text { country } \\
\text { economists }\end{array}$ \\
\hline $\begin{array}{l}\text { Expenditure ceilings } \\
\text { for line ministries }\end{array}$ & $\begin{array}{l}\text { The score is } 0 \text { if there are no ceilings; } 2 \text { if there are ceilings for some types of } \\
\text { expenditures; and } 4 \text { if there are ceilings for all types of expenditures. }\end{array}$ & $\begin{array}{l}\text { OECD, FAD } \\
\text { economists, } \\
\text { and IMF } \\
\text { country } \\
\text { economists }\end{array}$ \\
\hline
\end{tabular}




\begin{tabular}{|c|c|c|}
\hline \multicolumn{2}{|c|}{ Sustainability and Credibility } & \multirow[b]{2}{*}{$\begin{array}{l}\text { PEFA } \\
\text { reports, } \\
\text { OECD, and } \\
\text { ROSC }\end{array}$} \\
\hline $\begin{array}{l}\text { Medium-term } \\
\text { planning and } \\
\text { integration with } \\
\text { annual budget }\end{array}$ & $\begin{array}{l}\text { The score if } 0 \text { if the government does not prepare multi-year forecasts of fiscal } \\
\text { aggregates or the forecasts are not linked to the annual budget; } 1.33 \text { if the } \\
\text { forecasts for } 1-2 \text { years but there are no links to the annual budget; } 2.67 \text { if the } \\
\text { forecasts are for at least } 2 \text { years with some links to the annual budget; and } 4 \text { if } \\
\text { forecasts are for at least } 2-3 \text { years and there are clear links to the annual budget. }\end{array}$ & \\
\hline $\begin{array}{l}\text { Costed sector } \\
\text { strategies }\end{array}$ & $\begin{array}{l}\text { The score is } 0 \text { if sector strategies are not prepared OR there is no costing of } \\
\text { investments and recurrent expenditures; } 2 \text { if sector strategies exist in several } \\
\text { major sectors but are not fully costed OR are inconsistent with fiscal forecasts; } \\
\text { and } 4 \text { if sector strategies exist for most sectors with full costing of recurrent } \\
\text { expenditures and investment, broadly consistent with fiscal forecasts. }\end{array}$ & $\begin{array}{l}\text { PEFA } \\
\text { reports, } \\
\text { OECD, and } \\
\text { ROSC }\end{array}$ \\
\hline \multicolumn{3}{|l|}{$\begin{array}{l}\text { Macroeconomic and } \\
\text { fiscal forecasting } \\
\text { ( } 3 \text { part question - } \\
\text { score is average) }\end{array}$} \\
\hline $\begin{array}{l}\text { (i) Macroeconomic } \\
\text { forecasts discussed } \\
\text { in budget } \\
\text { documents. }\end{array}$ & $\begin{array}{l}\text { The score if } 0 \text { if no information related to macroeconomic assumptions and } \\
\text { forecasts is presented; } 2 \text { if partial information is provided, with some details } \\
\text { excluded; and } 4 \text { if full information is presented. }\end{array}$ & $\begin{array}{l}\text { IBP, ROSC, } \\
\text { and IMF } \\
\text { country } \\
\text { economists }\end{array}$ \\
\hline $\begin{array}{l}\text { (ii) Sensitivity } \\
\text { analysis discussed in } \\
\text { annual budget } \\
\text { documents }\end{array}$ & $\begin{array}{l}\text { The score is } 0 \text { if alternative medium-term scenarios are not discussed; } 2 \text { if the } \\
\text { discussion is incomplete or irregular; and } 4 \text { if alternative medium-term scenarios } \\
\text { are discussed for all assumptions. }\end{array}$ & $\begin{array}{l}\text { OECD, IBP, } \\
\text { and ROSC }\end{array}$ \\
\hline $\begin{array}{l}\text { (iii) Identification of } \\
\text { separate impact of } \\
\text { current vs. new } \\
\text { policies in budget } \\
\text { documents }\end{array}$ & $\begin{array}{l}\text { The score is } 0 \text { if no analysis is published; } 2 \text { if the analysis is partial or irregular; } \\
\text { and } 4 \text { if a comprehensive analysis is presented. }\end{array}$ & $\begin{array}{l}\text { OECD, IBP, } \\
\text { ROSC, and } \\
\text { PEFA reports }\end{array}$ \\
\hline
\end{tabular}




\begin{tabular}{|c|c|c|}
\hline \multicolumn{2}{|l|}{ Comprehensiveness } & \multirow[b]{2}{*}{$\begin{array}{l}\text { OECD, ROSC, } \\
\text { and FAD } \\
\text { economists }\end{array}$} \\
\hline Dual Budgeting & $\begin{array}{l}\text { The score is } 0 \text { if there are separate budgets for recurrent expenditures and for } \\
\text { capital investment; and } 4 \text { if the budget includes both recurrent spending and } \\
\text { capital investment. }\end{array}$ & \\
\hline $\begin{array}{l}\text { Extra-budgetary } \\
\text { expenditure }\end{array}$ & $\begin{array}{l}\text { The score is } 0 \text { if the level of unreported extra-budgetary expenditure is more } \\
\text { than } 10 \text { percent of GDP; } 1.33 \text { if it is between } 5-10 \text { percent of GDP; } 2.67 \text { if it } \\
\text { is between } 2-5 \text { percent of GDP; and } 4 \text { if it is below } 1 \text { percent of GDP. }\end{array}$ & $\begin{array}{l}\text { PEFA reports, } \\
\text { OECD, and } \\
\text { ROSC }\end{array}$ \\
\hline $\begin{array}{l}\text { Inclusion of information } \\
\text { on donor-funded projects }\end{array}$ & $\begin{array}{l}\text { The score is } 0 \text { if information on donor-financed projects is not included in } \\
\text { the budget or information is seriously deficient; } 2 \text { if partial information is } \\
\text { included; and } 4 \text { if detailed information for a large share of donor-funded } \\
\text { projects is included. }\end{array}$ & $\begin{array}{l}\text { PEFA reports, OECD, } \\
\text { and IBP }\end{array}$ \\
\hline $\begin{array}{l}\text { Inclusion of information } \\
\text { on government debt }\end{array}$ & $\begin{array}{l}\text { The score is } 0 \text { if data on outstanding domestic and external debt are not } \\
\text { included in the budget or other supporting documents; } 2 \text { if partial } \\
\text { information is included; and } 4 \text { if comprehensive information is included. }\end{array}$ & $\begin{array}{l}\text { IBP, OECD, and PEFA } \\
\text { reports }\end{array}$ \\
\hline $\begin{array}{l}\text { Overview of aggregate } \\
\text { fiscal risk in budget } \\
\text { documents. }\end{array}$ & $\begin{array}{l}\text { The score is } 0 \text { if there is little or no formal disclosure or evaluation of fiscal } \\
\text { risks in the budget documents; } 1 \text { if there is partial disclosure; and } 2 \text { if fiscal } \\
\text { risks are discussed comprehensively and significant quantitative information } \\
\text { is included. }\end{array}$ & $\begin{array}{l}\text { OECD, ROSC, and } \\
\text { PEFA reports }\end{array}$ \\
\hline \multicolumn{3}{|l|}{ Transparency } \\
\hline $\begin{array}{l}\text { Classification of the } \\
\text { budget }\end{array}$ & $\begin{array}{l}\text { The score is } 0 \text { if expenditures for the budget year are only based on an } \\
\text { administrative classification; } 2 \text { if they are based on an administrative and } \\
\text { economic classification; and } 4 \text { if they are based on an administrative, } \\
\text { economic and sub-functional (or programmatic) classification. }\end{array}$ & $\begin{array}{l}\text { IBP, PEFA reports, } \\
\text { and } \\
\text { ROSC }\end{array}$ \\
\hline $\begin{array}{l}\text { Publication of the } \\
\text { executive's budget } \\
\text { proposal (draft budget) }\end{array}$ & $\begin{array}{l}\text { The score is } 0 \text { if the draft budget is not published; } 2 \text { if only a few key parts } \\
\text { are published; and } 4 \text { if the draft budget is published entirely. }\end{array}$ & $\begin{array}{l}\text { IBP, ROSC, and PEFA } \\
\text { reports }\end{array}$ \\
\hline
\end{tabular}




\begin{tabular}{|c|c|c|}
\hline \multicolumn{2}{|l|}{ Budget Approval } & \\
\hline \multicolumn{2}{|l|}{ Top-down Budgeting } & \\
\hline $\begin{array}{l}\text { Limits to } \\
\text { amendments by the } \\
\text { legislature }\end{array}$ & $\begin{array}{l}\text { The score is } 0 \text { if the legislature is not entitled to make any amendments to the } \\
\text { proposed budget, or if there are no clear limits on the legislature's rights to } \\
\text { amend the budget; } 2 \text { if legislature can introduce fiscally neutral amendments to } \\
\text { the budget; and } 4 \text { if the legislature can change the composition of expenditures, } \\
\text { but not increase the proposed budget deficit, nor total expenditures. }\end{array}$ & $\begin{array}{l}\text { OECD, IBP, ROSC, } \\
\text { and FAD economists }\end{array}$ \\
\hline $\begin{array}{l}\text { Top-down sequence } \\
\text { of budget approval }\end{array}$ & $\begin{array}{l}\text { The score is } 0 \text { if the legislature does not first approve the overall annual budget } \\
\text { framework for total revenues and expenditures; and } 4 \text { if the legislature first } \\
\text { approves the overall annual fiscal framework, then votes on the detailed } \\
\text { expenditures within the approved "top down" constraints. }\end{array}$ & $\begin{array}{l}\text { OECD and FAD } \\
\text { economists }\end{array}$ \\
\hline \multicolumn{2}{|l|}{ Rules and Controls } & \\
\hline $\begin{array}{l}\text { Time limits for } \\
\text { budget approval }\end{array}$ & $\begin{array}{l}\text { The score is } 0 \text { if there is no clear time frame for presenting and approving the } \\
\text { budget; } 2 \text { if the budget has to be approved before the start of the fiscal year (FY), } \\
\text { but is presented to legislature only } 1-2 \text { months before the start of the year; and } 4 \\
\text { if budget has to be presented at least three months prior to start of the FY, and } \\
\text { approved before the start of the year. }\end{array}$ & $\begin{array}{l}\text { OECD, ROSC, and } \\
\text { FAD economists }\end{array}$ \\
\hline \multicolumn{2}{|c|}{ Sustainability and Credibility } & \\
\hline $\begin{array}{l}\text { Scope of legislative } \\
\text { scrutiny }\end{array}$ & $\begin{array}{l}\text { The score is } 0 \text { if the legislature is not consulted on the government's overall } \\
\text { fiscal strategy, or if there is no functioning legislature; } 1.33 \text { if the legislature's } \\
\text { review only covers details of expenditure and revenue; } 2.67 \text { if the legislature's } \\
\text { review only covers details of expenditure and revenue and fiscal policies and } \\
\text { aggregates; and } 4 \text { if the legislature's review covers fiscal policies, the medium- } \\
\text { term framework and spending priorities, as well as details of expenditure and } \\
\text { revenue. }\end{array}$ & $\begin{array}{l}\text { PEFA reports and } \\
\text { OECD }\end{array}$ \\
\hline
\end{tabular}




\begin{tabular}{|c|c|c|}
\hline \multicolumn{2}{|l|}{ Comprehensiveness } & \multirow[b]{2}{*}{$\begin{array}{l}\text { PEFA reports and } \\
\text { OECD }\end{array}$} \\
\hline $\begin{array}{l}\text { Information } \\
\text { contained in budget } \\
\text { document presented } \\
\text { to the legislature }\end{array}$ & $\begin{array}{l}\text { The score is } 0 \text { if budget documentation presented to legislature covers little or no } \\
\text { relevant information on policy objectives, macroeconomic assumptions, budget } \\
\text { priorities, and medium-term priorities; } 2 \text { if partial information on these elements } \\
\text { is included; and } 4 \text { if comprehensive information is presented. }\end{array}$ & \\
\hline \multicolumn{2}{|l|}{ Transparency } & \\
\hline $\begin{array}{l}\text { Public hearings on } \\
\text { overall budget policy }\end{array}$ & $\begin{array}{l}\text { The score is } 0 \text { if no public hearings are held by the legislature on the overall } \\
\text { budget framework; } 2 \text { if no public hearings are held but summaries or reports are } \\
\text { published; and } 4 \text { if public hearings are held. }\end{array}$ & $\begin{array}{l}\text { IBP, ROSC, and IMF } \\
\text { country economists }\end{array}$ \\
\hline \multicolumn{2}{|c|}{ Budget Implementation } & \\
\hline \multicolumn{2}{|l|}{ Top-down Budgeting } & \\
\hline $\begin{array}{l}\text { Appropriations } \\
\text { received by line } \\
\text { ministries }\end{array}$ & $\begin{array}{l}\text { The score is } 0 \text { if line ministries receive lump sum appropriations without sub- } \\
\text { limits or guidelines; } 2 \text { if appropriations received specify only some types of } \\
\text { expenditures (for example capital expenditures); and } 4 \text { if appropriations specify } \\
\text { all expenditures. }\end{array}$ & $\begin{array}{l}\text { OECD, FAD } \\
\text { economists, and IMF } \\
\text { country economists }\end{array}$ \\
\hline \multicolumn{2}{|l|}{ Rules and Controls } & \\
\hline $\begin{array}{l}\text { Existence and } \\
\text { effectiveness of } \\
\text { internal controls }\end{array}$ & $\begin{array}{l}\text { The score is } 0 \text { if commitment control systems are generally lacking or routinely } \\
\text { violated; } 2 \text { if such controls exist, but do not cover all expenditures, or are } \\
\text { occasionally violated; and } 4 \text { if comprehensive expenditure commitment controls } \\
\text { are in place and compliance with rules is high. }\end{array}$ & $\begin{array}{l}\text { PEFA reports and } \\
\text { ROSC }\end{array}$ \\
\hline $\begin{array}{l}\text { In-year amendments } \\
\text { to the budget }\end{array}$ & $\begin{array}{l}\text { The score is } 0 \text { if there are no rules regarding in-year amendments to the budget, } \\
\text { or rules are rudimentary, unclear and not respected; } 1.33 \text { if rules exist but are } \\
\text { often respected and allow for big reallocations; } 2.67 \text { if clear rules exist and are } \\
\text { usually respected; and } 4 \text { if clear rules exist which place strict limits on the extent } \\
\text { and nature of amendments, and are consistently respected. }\end{array}$ & $\begin{array}{l}\text { PEFA reports and } \\
\text { OECD }\end{array}$ \\
\hline
\end{tabular}




\begin{tabular}{|c|c|c|}
\hline Internal audit & $\begin{array}{l}\text { The score is } 0 \text { if there is no internal audit system; } 2 \text { if internal audits are } \\
\text { functional for some entities and partially meet recognized international standards; } \\
\text { and } 4 \text { if internal audits exist for all entities and generally meet international } \\
\text { standards. }\end{array}$ & $\begin{array}{l}\text { OECD, PEFA } \\
\text { reports, and ROSC }\end{array}$ \\
\hline External audit & $\begin{array}{l}\text { The score is } 0 \text { if audits cover less than } 50 \text { percent of total central government } \\
\text { expenditures; } 2 \text { if at least } 50 \text { percent or more of total central government } \\
\text { expenditures are audited annually; and } 4 \text { if all expenditures are audited and the } \\
\text { full range of financial audits is in compliance with auditing standards. }\end{array}$ & $\begin{array}{l}\text { PEFA reports and } \\
\text { IBP }\end{array}$ \\
\hline \multicolumn{3}{|l|}{$\begin{array}{l}\text { Sustainability and } \\
\text { Credibility }\end{array}$} \\
\hline $\begin{array}{l}\text { Monitoring of public } \\
\text { enterprises and } \\
\text { subnational } \\
\text { governments }\end{array}$ & $\begin{array}{l}\text { The score is } 0 \text { if no annual monitoring takes places or it is significantly } \\
\text { incomplete; } 2 \text { if there is partial monitoring and oversight of public enterprises } \\
\text { and fiscal position of subnational governments; and } 4 \text { if all major public } \\
\text { enterprises submit fiscal reports, including annual audited accounts, to the central } \\
\text { government and net fiscal position of all levels of sub national governments is } \\
\text { monitored at least annually. }\end{array}$ & $\begin{array}{l}\text { PEFA reports and } \\
\text { ROSC }\end{array}$ \\
\hline $\begin{array}{l}\text { Recording and } \\
\text { management of } \\
\text { domestic and } \\
\text { external debt }\end{array}$ & $\begin{array}{l}\text { The score is } 0 \text { if data on domestic and external debt are incomplete and } \\
\text { inaccurate to a significant degree; } 2 \text { if such data are complete, updated and } \\
\text { reconciled at least annually; and } 4 \text { if the data are complete, updated and } \\
\text { reconciled on a monthly/quarterly basis with comprehensive reports produced. }\end{array}$ & $\begin{array}{l}\text { PEFA reports and } \\
\text { ROSC }\end{array}$ \\
\hline $\begin{array}{l}\text { Stock and } \\
\text { monitoring of } \\
\text { expenditure arrears. }\end{array}$ & $\begin{array}{l}\text { The score is } 0 \text { if the stock of arrears exceeds } 10 \text { percent of total expenditure, or } \\
\text { no data are available on arrears; } 2 \text { if the stock of arrears is between } 2-10 \text { percent } \\
\text { of total budgeted expenditure and partial data is available; and } 4 \text { if the there are } \\
\text { no arrears, or the stock of arrears is low (below } 2 \text { percent of total expenditure), } \\
\text { and comprehensive data are available. }\end{array}$ & PEFA reports \\
\hline
\end{tabular}




\begin{tabular}{|c|c|c|}
\hline Transparency & & \\
\hline $\begin{array}{l}\text { Accounting } \\
\text { Standards }\end{array}$ & $\begin{array}{l}\text { The score is } 0 \text { if the ministry of finance or CBA determine standards, or } \\
\text { standards are determined on an ad-hoc basis; } 2 \text { if standards are determined by an } \\
\text { advisory board established by law or an independent standards board; and } 4 \text { if } \\
\text { generally accepted international accounting standards are followed. }\end{array}$ & $\begin{array}{l}\text { OECD, FAD } \\
\text { economists, and IMF } \\
\text { country economists }\end{array}$ \\
\hline $\begin{array}{l}\text { Completeness and } \\
\text { timeliness of } \\
\text { financial statements }\end{array}$ & $\begin{array}{l}\text { The score is } 0 \text { if a consolidated financial statement is either not prepared or } \\
\text { essential information is missing, and if such a statement is not submitted for } \\
\text { external audit within } 15 \text { months of the end of fiscal year; } 2 \text { if a consolidated but } \\
\text { incomplete statement is prepared annually, and is made available for external } \\
\text { audit within } 10-15 \text { months of the year end; and } 4 \text { if a comprehensive } \\
\text { consolidated statement is prepared annually and submitted for external audit } \\
\text { within } 6-10 \text { months of the year end. }\end{array}$ & $\begin{array}{l}\text { PEFA reports and } \\
\text { ROSC }\end{array}$ \\
\hline $\begin{array}{l}\text { Legislative scrutiny } \\
\text { of external audit }\end{array}$ & $\begin{array}{l}\text { The score is } 0 \text { if there is no examination of audit reports by the legislature; } 2 \text { if } \\
\text { there is partial scrutiny by the legislature, but often with a considerable delay; } \\
\text { and } 4 \text { if scrutiny of audit reports is comprehensive, and generally completed } \\
\text { within } 3 \text { months. }\end{array}$ & $\begin{array}{l}\text { PEFA reports and } \\
\text { IBP }\end{array}$ \\
\hline $\begin{array}{l}\text { Scope and timeliness } \\
\text { of in-year reports }\end{array}$ & $\begin{array}{l}\text { The score is } 0 \text { if quarterly reports are not prepared, or are issued with a } \\
\text { significant delay and do not allow for a comparison with the original budget; } 2 \text { if } \\
\text { reports are prepared quarterly, but issued within } 6-8 \text { weeks of the quarter-end } \\
\text { and partial comparison to the original budget is possible; and } 4 \text { if reports are } \\
\text { prepared quarterly or more frequently, and issued within } 4 \text { weeks of end of the } \\
\text { quarter-end, and classification of data allows direct comparison with the original } \\
\text { budget. }\end{array}$ & $\begin{array}{l}\text { PEFA reports, IBP, } \\
\text { and ROSC }\end{array}$ \\
\hline $\begin{array}{l}\text { Publication and } \\
\text { scope of year-end } \\
\text { reports }\end{array}$ & $\begin{array}{l}\text { The score is } 0 \text { if the report is not released, or no explanation of the differences } \\
\text { between the enacted expenditure levels and the actual outcomes is provided; } 2 \text { if } \\
\text { annual report is published but limited explanation of differences between enacted } \\
\text { and actual expenditure levels is provided; and } 4 \text { if annual report is published and } \\
\text { there is detailed explanation of the differences between the enacted expenditure } \\
\text { levels and the actual outcomes. }\end{array}$ & $\begin{array}{l}\text { IBP, ROSC, and IMF } \\
\text { country economists }\end{array}$ \\
\hline
\end{tabular}




\section{Appendix III. Sensitivity Analysis}

In this section we examine the robustness of our constructed indices to alternative aggregation methodologies. We consider the following alternatives:

- Indices with different weights. We altered the set of weights assigned to various dimensions to assess whether the approach considered in the paper is robust to alternative weighting schemes. Expert assessments based on considerable technical assistance point to the relative importance of budget planning and implementation stages over approval. Similarly, across categories, rules and controls and comprehensiveness are viewed as more critical than the other categories. To capture this, we analyze the following two overall indices with different weights:

$$
\text { STAGE INDEX (different weights })=\frac{1}{3}\left(0.4 \times S_{1}+0.2 \times S_{2}+0.4 \times S_{3}\right),
$$

where the $S_{1}=$ PLANNING, $S_{2}=$ APPROVAL, and $S_{3}=$ IMPLEMENTATION are the sub-indices defined earlier. Similarly, for the overall category index we consider the following formulation:

CATEGORY INDEX (different weights $)=\frac{1}{5}\left(0.15 \times C_{1}+0.3 \times C_{2}+0.1 \times C_{3}+0.3 \times C_{4}+0.15 \times C_{5}\right)$,

where the sub-indices $C_{1}=$ TOPDOWN, $C_{2}=$ RULES, $C_{3}=$ SUSTAINABILITY, $C_{4}=$ COMPREHENSIVENESS, and $C_{5}=$ TRANSPARENCY are as defined earlier.

- Indices with different assumptions about substitutability. Assigning equal weights in the additive aggregation procedure considered in the paper implicitly assumes that the subindices are perfect substitutes. This implies that the indices do not differentiate between countries having intermediate scores for each institutional component and countries that have high scores in some components and low scores in others. In order to investigate if different assumptions about the substitutability of index components significantly change the ranking of countries, we construct the following overall indices for the stages and categories:

$$
\operatorname{STAGE} \operatorname{INDEX}(\alpha)=\frac{1}{3} \sum_{i=1}^{3}\left(S_{i}\right)^{\alpha},
$$

and

$$
\text { CATEGORY INDEX }(\alpha)=\frac{1}{5} \sum_{i=1}^{5}\left(C_{i}\right)^{\alpha},
$$

Note that the indices differ from the original additive aggregation if $\alpha$ does not equal 1 . For $\alpha>1$, the aggregate score of an index will be higher for countries that have high scores in some stages (or categories) and low scores in others than for those countries which have 
more balanced scores around medium score values. In contrast, if $0<\alpha<1$, the aggregate score is lower for countries that have high scores in some stages (or categories) and low scores in others than for those countries which have more balanced scores.

- Multiplicative Indices. Additive aggregation is appropriate if budget institutions are substitutes, while multiplying the values of the institutional variables would be appropriate if institutions were complements. It is quite reasonable to assume that complementary effects exist between each subsequent stages of the budget process. Consider, for example, the interaction between the planning and negotiation and the subsequent approval stage. If the legislative authority can easily deviate from the government's estimates, then planned budgetary decisions at the executive level will have only a weak disciplining effect on excessive spending or deficits at the approval stage. To take into account the possible complementary interaction between the different stages of the budget process, we use the following formula: MULTIPLICATIVE STAGE INDEX $=S_{1} \times S_{2} \times S_{3}$,

Similarly it is possible to think that the categories should be complementary. In this case, we consider the following formula: MULTIPLICATIVE CATEGORY INDEX $=C_{1} \times C_{2} \times C_{3} \times C_{4} \times C_{5}$,

The disadvantage of the multiplicative aggregation procedure, however, is that it is very sensitive to specification errors. If, for example, a stage or a category is falsely assigned a low score, while the country actually possesses all institutional characteristics to be ranked high, multiplicative aggregation results in a larger error in the overall score than additive aggregation.

Table A1 reports Spearman rank correlations for the overall stage and category indices under different types of aggregation. Following Alesina et al. (1999), we choose 0.4 and 2 as alternative values for $\alpha$. The results show that both the original additive stage and category indices are highly correlated with all alternative indices. The correlations are significant at the one percent level. Therefore, different assumptions about the substitutability between stages of the budget process (or categories of the budget) do not have any significant effect on country rankings. 
Table A1. Spearman Rank Correlations between the Overall Indices

\begin{tabular}{lcc}
\hline & Stage Index & Category Index \\
\hline Category Index & $0.9696^{*}$ & \\
Stage Index with Different Weights & $0.9759^{*}$ & \\
Stage Index with $\alpha=0.4$ & $0.9983^{*}$ & \\
Stage Index with $\alpha=2$ & $0.9938^{*}$ & \\
Multiplicative Stage Index & $0.9950^{*}$ & \\
Stage Index & & $0.9696^{*}$ \\
Category Index with Different Weights & & $0.9743^{*}$ \\
Category Index with $\alpha=0.4$ & & $0.9967^{*}$ \\
Category Index with $\alpha=2$ & & $0.9964^{*}$ \\
Multiplicative Stage Index & & $0.9933^{*}$ \\
\hline
\end{tabular}

Note: * indicates that the correlation coefficient is significantly different from zero at the one percent.

A similar sensitivity analysis for different assumptions about substitutability was carried out for the sub-indices. Table A2 presents the results. All the Spearman rank-order correlations for the sub-indices are significant at the one percent level. Therefore, the original additive aggregation procedure appears to be appropriate to the extent that country rankings are robust to changes in specification. As a result, in the empirical analysis, the simple additive sub-indices can be utilized.

Table A2. Spearman Rank Correlations between the Sub-Indices

\begin{tabular}{|c|c|c|c|c|c|c|c|c|}
\hline & Planning & Approval & Implementation & $\begin{array}{l}\text { Top Down } \\
\text { Procedures }\end{array}$ & $\begin{array}{l}\text { Rules and } \\
\text { Controls }\end{array}$ & $\begin{array}{l}\text { Sustainability } \\
\text { and } \\
\text { Credibility }\end{array}$ & Comprehensiveness & Transparency \\
\hline Planning with $\alpha=0.4$ & $0.9758^{*}$ & & & & & & & \\
\hline Planning with $\alpha-2$ & $0.9825^{*}$ & & & & & & & \\
\hline Approval with $\alpha=0.4$ & & $0.9638 *$ & & & & & & \\
\hline Approval with $\alpha=2$ & & $0.9634^{*}$ & $0.9690^{*}$ & & & & & \\
\hline Implementation with $\alpha=0.4$ & & & $0.9526^{*}$ & & & & & \\
\hline Implementation with $a=2$ & & & & & & & & \\
\hline Top-Down Procedurcs with $\alpha=0.4$ & & & & $0.9773^{*}$ & & & & \\
\hline Top-Down Procedures with $\alpha=2$ & & & & $0.9673^{*}$ & & & & \\
\hline Rules and Controls with $\alpha=0.4$ & & & & & $0.9324^{*}$ & & & \\
\hline Rules and Controk with $a=2$ & & & & & $0.8942 *$ & & & \\
\hline Sustainability and Credibility with $\alpha=0.4$ & & & & & & $0.9649 *$ & & \\
\hline Sustainability and Credibility with $a=2$ & & & & & & $0.9705 *$ & & \\
\hline Comprehens iveness with $\alpha=0.4$ & & & & & & & $0.9822 *$ & \\
\hline Comprehensiveness with $\alpha=2$ & & & & & & & $0.9845 *$ & \\
\hline Transparency with $\alpha=0.4$ & & & & & & & & $0.9661^{*}$ \\
\hline Transparcncy with $\alpha-2$ & & & & & & & & $0.9486^{*}$ \\
\hline
\end{tabular}

Note: * indicates that the correlation coefficient is significantly dfferent from zero at the one percent. 
Appendix IV. Definition and Sources of Variables

\begin{tabular}{|c|c|c|}
\hline Variable & Description & Source \\
\hline Stage index & Index (see text) & IMF staff calculations \\
\hline Category index & Index (see text) & IMF staff calculations \\
\hline Primary balance & Central government primary balance & WEO, IMF \\
\hline Extermal debt & Official Publc external debt in USS & $\begin{array}{l}\text { Global Development } \\
\text { Finance, Wonld Bank; } \\
\text { WEO, IMF }\end{array}$ \\
\hline $\begin{array}{l}\text { Real growth in central government } \\
\text { spending }\end{array}$ & $\begin{array}{l}\text { Growth in nominal central government total spending } \\
\text { deflated using the CPI. }\end{array}$ & WEO, IMF \\
\hline Growth & Real GDP growth rate & WEO, IMF \\
\hline Terms of trade & Growth in commodity terms of trade & WEO, IMF \\
\hline Trade & $\begin{array}{l}\text { Product of anmal growth in commodity terms of trade times } \\
\text { the degree of openness of the economy (exports phes } \\
\text { imports divided by GDP). }\end{array}$ & WEO, IMF \\
\hline Inflation & Growth in consumer price index & WEO, IMF \\
\hline Intial GDP per capita & GDP per capita in PPP terms in 2002. & Penn Wordd Tables \\
\hline Dependency ratio & Ratio of population under 15 years of age & WEO, IMF \\
\hline Comuption & Governance indicators & $\begin{array}{l}\text { World Bank, Kaufman and Kraay } \\
\text { govermance indicators }\end{array}$ \\
\hline Government effectiveness & Governance indicators & $\begin{array}{l}\text { World Bank, Kaufiman and Kraay } \\
\text { govemance indicators }\end{array}$ \\
\hline Regional dummy & A dummy reflecting a country's region location & IMF \\
\hline Ethic fractiomaliation & Index of fractionalization in ethricity & Alesima et al (2002) \\
\hline IMF dummy & A dummy reflecting IMF program engagement & IMF \\
\hline HIPC dummy & $\begin{array}{l}\text { Equal to } 1 \text { if the coumtry reached the completion poirt for } \\
\text { HIPC initiative assistance }\end{array}$ & IMF \\
\hline \multirow[t]{2}{*}{ Oil dummy } & Equal to 1 if the country is an oitexporter. & WEO, IMF \\
\hline & & Wordd Bank \\
\hline Low-income dumny & $\begin{array}{l}\text { Equal to } 1 \text { if the courtry is eligible for the PRGT at end- } \\
\text { December } 2009 .\end{array}$ & IMF \\
\hline
\end{tabular}

